\title{
Sexual dimorphism in bacterial infections
}

\author{
Edgar Ricardo Vázquez-Martínez , Elizabeth García-Gómez², Ignacio Camacho-Arroyo \\ and Bertha González-Pedrajo ${ }^{3^{*}}$
}

\begin{abstract}
Background: Sex differences are important epidemiological factors that impact in the frequency and severity of infectious diseases. A clear sexual dimorphism in bacterial infections has been reported in both humans and animal models. Nevertheless, the molecular mechanisms involved in this gender bias are just starting to be elucidated. In the present article, we aim to review the available data in the literature that report bacterial infections presenting a clear sexual dimorphism, without considering behavioral and social factors.

Main body: The sexual dimorphism in bacterial infections has been mainly attributed to the differential levels of sex hormones between males and females, as well as to genetic factors. In general, males are more susceptible to gastrointestinal and respiratory bacterial diseases and sepsis, while females are more susceptible to genitourinary tract bacterial infections. However, these incidences depend on the population evaluated, animal model and the bacterial species. Female protection against bacterial infections and the associated complications is assumed to be due to the pro-inflammatory effect of estradiol, while male susceptibility to those infections is associated with the testosterone-mediated immune suppression, probably via their specific receptors. Recent studies indicate that the protective effect of estradiol depends on the estrogen receptor subtype and the specific tissue compartment involved in the bacterial insult, suggesting that tissue-specific expression of particular sex steroid receptors contributes to the susceptibility to bacterial infections. Furthermore, this gender bias also depends on the effects of sex hormones on specific bacterial species. Finally, since a large number of genes related to immune functions are located on the X chromosome, X-linked mosaicism confers a highly polymorphic gene expression program that allows women to respond with a more expanded immune repertoire as compared with men.

Conclusion: Notwithstanding there is increasing evidence that confirms the sexual dimorphism in certain bacterial infections and the molecular mechanisms associated, further studies are required to clarify conflicting data and to determine the role of specific hormone receptors involved in the gender bias of bacterial infections, as well as their potential as therapeutic targets.
\end{abstract}

Keywords: Sexual dimorphism, Bacterial infection, Sex steroid hormones, Estradiol, Testosterone, Progesterone

\section{Background}

Frequency and severity of infectious diseases clearly vary between men and women. In general, males are more susceptible to diverse bacterial illnesses than their female counterparts [1]. This sexual dimorphism is evident throughout all life and starts during the infancy stage, when male predisposition to numerous bacterial infections is evident [2]. Variations between male and female

\footnotetext{
* Correspondence: bpedrajo@ifc.unam.mx

${ }^{3}$ Departamento de Genética Molecular, Instituto de Fisiología Celular, UNAM, Ciudad Universitaria, Av. Universidad 3000, Coyoacán, 04510 Ciudad de México, Mexico

Full list of author information is available at the end of the article
}

individuals in the progression and outcome of infections are intimately linked to genetic, biological, and behavioral differences, which include several factors such as the exposure to certain pathogens, sex steroid hormones, and the development of different immune responses [3-5].

In regard to genetic differences, the $\mathrm{X}$ chromosome contains several genes implicated in the immune response, such as genes encoding Toll-like receptors (TLR-7 and 8), cytokine receptors, transcription factors, and proteins that participate in the activity of $\mathrm{T}$ and $\mathrm{B}$ cells $[6,7]$. During embryonic development, one $\mathrm{X}$ chromosome is randomly inactivated in females, but some genes are not silenced, providing women an 
immune advantage [3, 8], who present stronger and more controlled innate and adaptive immune responses than men $[3,6]$.

Sex hormones, besides their multiple roles in reproductive tissues, are able to influence immune cells by modulating their activity in response to infections (Fig. 1). According to the classic mechanism of progesterone (P4), estradiol (E2), and testosterone (T4) action, their cognate receptors progesterone receptor (PR), estrogen receptor (ER), and androgen receptor (AR), respectively, interact with chaperone Hsp90/co-chaperone complexes prior to their binding to hormones. When hormones diffuse into their target cell and interact with their cognate receptor, they induce a conformational change that promotes the dissociation of the chaperone/ co-chaperone complex from the hormone receptor with the concomitant receptor dimerization and phosphorylation. Then, the hormone-receptor complex is translocated into the nucleus and binds to specific hormone response elements (HRE) of target genes, which allows the recruiting of co-activators, chromatin remodeling complexes, the basal transcription machinery, and the RNA polymerase II to induce gene expression [9].

Sex steroid hormone receptors have been identified in diverse cells of the immune system [3]. For example, intracellular and membrane-bound ARs have been reported in $\mathrm{T}$ and $\mathrm{B}$ lymphocytes [10], while ERs are present in macrophages, neutrophils, natural killer (NK) cells, and lymphocytes $[11,12]$. PRs have also been detected in $\mathrm{T}$ and $\mathrm{B}$ lymphocytes, mast cells, eosinophils,
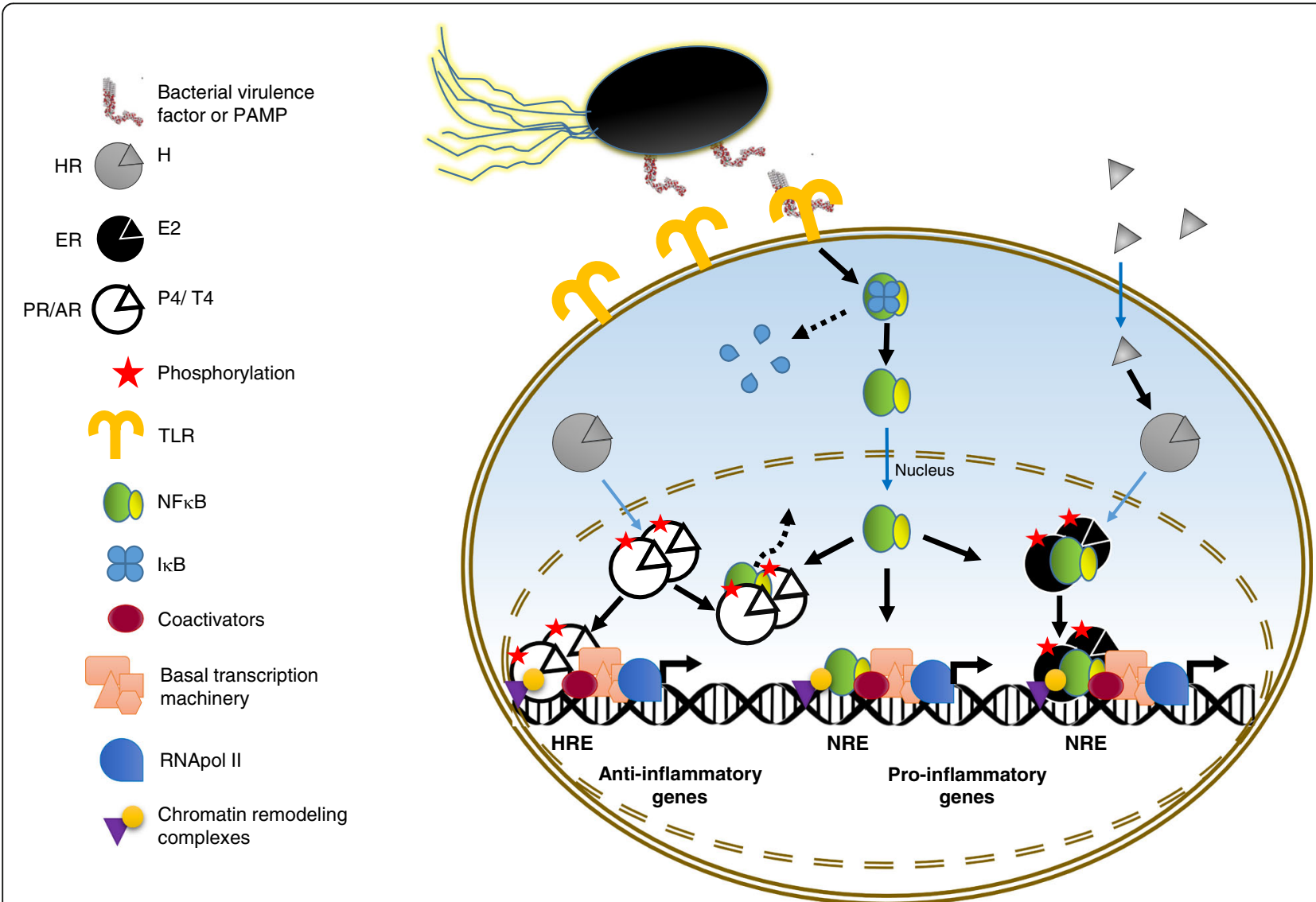

Fig. 1 Sex hormone effects in the expression of inflammatory mediators during bacterial infections. A schematic representation of the classic mechanism of action of progesterone (P4), estradiol (E2), and testosterone (T4) (for details, see the text), as well as the cross-talk with inflammatory signaling during bacterial infections is depicted. When bacterial virulence factors or pathogen-associated molecular patterns (PAMPs) are detected through host pattern recognition receptors such as Toll-like receptors (TLRs), signaling pathways are activated, allowing dissociation of the transcription factor NFKB from its inhibitor IKB, which is subsequently phosphorylated and degraded. Active NFkB is translocated into the nucleus and binds to response elements (NREs) of target genes, allowing the expression of pro-inflammatory genes. In general, P4 induces the expression of anti-inflammatory mediators and probably downregulates the expression of pro-inflammatory factors by sequestering NFKB and inhibiting its activity (indicated by a discontinued line arrow). On the other hand, during early response to infections or sepsis, E2 and T4 display a differential inflammatory effect, in which the former induces the expression of pro-inflammatory mediators by forming a complex with $\mathrm{NFkB}$, and the latter promotes an anti-inflammatory effect. During late response to infections, E2 displays an anti-inflammatory response that prevents systemic damage, while T4 shows a persistent active pro-inflammatory response that triggers systemic damage (not shown). HR steroid hormone receptor, PR progesterone receptor, ER estrogen receptor, AR androgen receptor, HRE hormone response elements 
macrophages, and dendritic cells [13, 14]. Regarding the effect of sex steroid hormones on the immune system, mediated principally by regulating the NFKB transcription factor activity, testosterone generally functions as a suppressor at early stages of infection, but as an activator during the late response to infection, as it occurs during sepsis; whereas, estradiol acts as an activator, and progesterone functions as an immunosuppressive agent, mainly during pregnancy [4, 15-17] (Fig. 1). Therefore, in response to infections, females usually activate Th2 responses and produce high levels of interleukins (IL) IL-4, IL-5, and IL-10 [14, 18-20]. On the other hand, males present predominantly Th1 responses and overproduce tumor necrosis factor $\alpha$ (TNF-U $\alpha$ ), IL-1 $\beta$, IL-2, IL-6, and IL-8, which in turn are frequently associated with inappropriate outcomes such as sepsis and bacteremia [21-24]. Besides, women show both higher baseline levels and elevated production of immunoglobulins (Ig) in response to bacterial challenge than men, in particular, IgM $[1,19]$.

Aging and menopause also influence the immune system function, increasing the predisposition to infections [25]. During menopause, there is a significant reduction in sex steroid hormone synthesis with a concomitant decrease in immune cell levels and their functional capacity $[1,25]$. Postmenopausal women and women with induced menopause due to surgical elimination of the ovaries have reduced levels of $\mathrm{B}$ cells and antiinflammatory cytokines, IL-4, and interferon $\gamma$ (IFN $\gamma$ ), while NK cell activity and levels of pro-inflammatory cytokines such as TNF- $\alpha$, IL-1 $\beta$, IL2, and IL- 6 are increased [26-29]. These effects are partially reversed with hormone replacement therapy [25, 27], which corroborates the significant role of sex steroid hormones in the immune system function.

In agreement with the aforementioned studies, development of bacterial infections depends on the influence of gender-associated factors such as sex steroid hormones, through the modulation of differential immune responses between women and men. The aim of the present article is to review the available data in the literature about bacterial infections that present a clear sexual dimorphism, such as gastrointestinal and respiratory infections, and sepsis, among others (Table 1). Although there is increasing evidence that confirms the sexual dimorphism in certain bacterial infections and the molecular mechanisms associated, further studies are required to clarify conflicting data and to determine

Table 1 Gender preference in bacterial infections

\begin{tabular}{|c|c|c|c|c|}
\hline Type of infection & $\begin{array}{l}\text { Gender } \\
\text { preference }\end{array}$ & Main bacteria species & Associated diseases or complications & References \\
\hline \multirow{7}{*}{$\begin{array}{l}\text { Gastrointestinal tract } \\
\text { infections }\end{array}$} & \multirow[t]{6}{*}{ Men } & Salmonella typhi & Typhoid ileal perforation & {$[30]$} \\
\hline & & Campylobacter jejuni & Inflammatory bowel disease & {$[37,38]$} \\
\hline & & Helicobacter pylori & Gastritis, peptic ulcer, and gastric cancer & [39] \\
\hline & & Clostridium difficile & Fulminant colitis & {$[47,48]$} \\
\hline & & Yersinia enterocolitica & Enteritis, enterocolitis, and gastroenterocolitis & {$[52]$} \\
\hline & & Vibrio spp. & Gastroenteritis and wound infections & {$[57,200,245,246]$} \\
\hline & Women & $\begin{array}{l}\text { Enterohemorrhagic } \\
\text { Escherichia coli }\end{array}$ & $\begin{array}{l}\text { Hemolytic-uremic syndrome and irritable bowel } \\
\text { syndrome }\end{array}$ & {$[59,60]$} \\
\hline \multirow{3}{*}{$\begin{array}{l}\text { Respiratory tract } \\
\text { infections }\end{array}$} & \multirow[t]{3}{*}{ Men } & Streptococcus pneumoniae & Community-acquired pneumonia & [79] \\
\hline & & Mycobacterium tuberculosis & Tuberculosis & {$[93-100]$} \\
\hline & & Legionella spp. & Legionnaires' disease & {$[131,132,141,133-140]$} \\
\hline $\begin{array}{l}\text { Bloodstream } \\
\text { infections }\end{array}$ & Men & Many bacterial species & Septic shock, organ dysfunction, severe sepsis & $\begin{array}{l}{[18,162,177,163,165-167,} \\
173-176]\end{array}$ \\
\hline $\begin{array}{l}\text { Urinary tract } \\
\text { infections }\end{array}$ & Women & Escherichia coli & Acute cystitis, inflammation, and sepsis & {$[229,231]$} \\
\hline Lyme borreliosis & Women & Borrelia burgdorferi & Erythema migrans and facial nerve palsy & {$[232,233]$} \\
\hline \multirow[t]{2}{*}{$\begin{array}{l}\text { Sexually transmitted } \\
\text { infections }\end{array}$} & \multirow[t]{2}{*}{ Women } & Chlamydia trachomatis & $\begin{array}{l}\text { Infertility, ectopic pregnancy, and pelvic inflammatory } \\
\text { disease }\end{array}$ & {$[235,237]$} \\
\hline & & Neisseria gonorrhea & Gonorrhea, pelvic inflammatory disease & [234] \\
\hline Listeriosis & Women & Listeria monocytogenes & Bacteremia, meningitis & [241] \\
\hline Q fever & Men & Coxiella burnetii & $\begin{array}{l}\text { Fever, granulomatous hepatitis, myocarditis, pericarditis, } \\
\text { and pneumonia }\end{array}$ & [243] \\
\hline Wound infections & Men & Mycobacterium marinum & $\begin{array}{l}\text { Swimming-pool granuloma or fish-tank granuloma } \\
\text { disease }\end{array}$ & [245] \\
\hline
\end{tabular}


the role of specific sex hormone receptors in the gender bias of bacterial infections, as well as their role as possible therapeutic targets.

\section{Sexual dimorphism and bacterial infections in the gastrointestinal tract}

Certain gastrointestinal infections are more recurrent and severe in men than in women. This sexual dimorphism can be explained in part because of behavioral differences during hygiene and eating practices, such as handwashing before food handling and eating, storage, refrigeration, and defrosting practices, and tendency of men to eat undercooked or raw food, as well as to ingest roadside food [30]. Although sexual dimorphism in gastrointestinal infections is mainly due to immune differences, these differences in turn can be influenced by the above mentioned behavioral dissimilarities between women and men. This is the case of typhoid fever and its complication: typhoid ileal perforation (TIP) [30]. TIP is characterized by an exacerbated inflammatory activity at Peyer's patches, probably in response to Salmonella typhi exposure and re-exposure events due to behavioral factors that favors infection in men.

During gastrointestinal injury, males produce predominantly pro-inflammatory cytokines, such as IL-6 and TNF- $\alpha$, as compared with females whose intestine produce anti-inflammatory factors such as IL-10 as well as protective factors of endothelial function such as a modest rise in nitric oxide (NO) levels [31]; in turn, the inflammatory response in males leads to perforation and cell necrosis at the site of infection [30]. Sex hormones signaling through their cognate receptors could play an important role in the progression of this pathology and their low incidence in women since both isoforms of ER (ER- $\alpha$ and ER- $\beta$ ) have been identified at Peyer's patches $[30,32]$, and estradiol induces $\mathrm{T}$ cell proliferation and activity, as well as production of anti-inflammatory cytokines [32]. The differential concentrations of sex hormones between men and women influence the type of immune response that is activated. Estradiol levels are higher in women (they rise up to $1250 \mathrm{pmol} / \mathrm{L}$ during the luteal menstrual phase) than those found in men (37-210 pmol/L), and the mean threshold required to induce production of anti-inflammatory factors and to suppress production of inflammatory cytokines is $690 \mathrm{pmol} / \mathrm{L}$; thus, an inflammatory balanced response is produced in females. On the other hand, testosterone that exhibits higher concentrations in men than in women (6.9-34.7 and 0.7-2.8 nmol/L, respectively), suppresses Th2 response and stimulates Th1 response in males, probably through the activity of ARs located in macrophages and lymphocytes that in turn regulate the differential production of cytokines, which favor the sexual dimorphism observed in this infection [33-35].
Additionally, in response to a bacterial stimulus, there is a differential expression of TLRs between females and males, which influences sexual dimorphism of gastrointestinal infections, since females show elevated levels of TLR2 and TLR4 in peritoneal macrophages and in consequence have a higher capacity to detect and eliminate pathogens than males [36].

Campylobacteriosis is another gastrointestinal infection that displays a sexual dimorphism [37]. This infection of zoonotic origin is caused by Campylobacter jejuni and provokes gastroenteritis, affecting predominantly men, especially young children. C. jejuni infections are related to the development of inflammatory bowel diseases and autoimmune pathologies such as Guillain-Barré syndrome $[37,38]$. It has been proposed that this tendency is caused by behavioral, environmental, and physiological factors. Strachan and collaborators used a mouse model of infection (Myd88 adaptor protein-deficient mice, which showed persistent colonization by $C$. jejuni to favor a stable infection), under controlled laboratory conditions that were established to minimize the effects of behavior and environment. They found that bacterial colonization was present in $100 \%$ of infected male mice, in contrast to $25 \%$ of infected females. Moreover, bacterial counts recovered from feces and different tissues were higher in male than in female rodents, supporting the influence of physiological differences between sexes on the prevalence of this bacterial disease in males [37]. However, more epidemiological and experimental studies are required to clarify and/or refuse the role played by environmental and behavioral factors in sexual dimorphism of campylobacteriosis.

In addition, infections caused by Helicobacter pylori affect predominantly males, and its outcomes, such as gastritis, peptic ulcer, and gastric cancer, are also more frequent in males. A possible explanation for this sexual dimorphism is the protective and vigorous immune response exerted by females during $H$. pylori infections via estrogens (probably through their specific receptors) [39, 40]. In this regard, estradiol treatment in males with gastroduodenal preneoplastic alterations reverts the histological modifications such as hyperplasia and dysplasia induced by the carcinogen agent $N$-methyl- $N^{\prime}$-nitro-nitrosoguanidine [41]. Moreover, male mice with gastric pathology induced by $H$. pylori infection have shown reduced expression of pro-inflammatory cytokines IFN- $\gamma$ and IL-1 $\beta$, increased expression levels of IL-10 and higher Th2-associated IgG1 responses after estradiol treatments. These findings have been associated with a reduction in the severity of gastric lesions caused by H. pylori [42].

Although cancer is not the subject of the present review, it is relevant to mention the protective effect of estrogens in order to explain their role and the ER participation during $H$. pylori infection to favor a 
successful outcome in females. It has been demonstrated in gastrointestinal cancer pathologies that cell proliferation pathways are regulated through ER- $\beta$. Inhibition of epithelial proliferation has been documented in a cell line of human gastric adenocarcinoma treated with $17 \beta$-estradiol [43]. Additionally, over-expression of ER- $\beta$ in ER- $\beta$-lacking HCT8 cells (human colon cancer) inhibited cell proliferation by modulating cell cycle regulators such as cyclin E, and producing cell cycle arrest at G1/S phase [44]. In another study, ER- $\beta$ activated by $17 \beta$-estradiol also has an inhibitory effect on colorectal cancer tumor proliferation, enhancing DNA mismatch repair by upregulating mRNA and protein levels of MLH1 [45], so a similar mechanism could also be involved in female protection against gastric cancer induced by $H$. pylori infection.

On the other hand, the expression of several H. pylori virulence factors is determined by other gender-specific host characteristics. Blood group antigen binding adhesin A (BabA) of $H$. pylori is a virulence factor important for bacterial binding to $\mathrm{ABO}$ blood group antigens expressed in the gastric epithelium and mucus layer (especially to $\mathrm{O} /$ $\mathrm{Le}^{\mathrm{b}}$ group) and to promote the translocation of CagA oncoprotein by the type IV secretion system into the host cell cytoplasm. Recently, it has been demonstrated that babA expression is elevated in H. pylori-infected male mice as compared with lack of expression in infected females. Additionally, males showed higher bacterial colonization levels than female mice. These findings are independent of adaptive immunity or TLR signaling; thus, other gender-associated factors such as gastric physiology and differential glycosylation patterns of blood antigens can be involved [46].

Clostridium difficile infections include diseases ranging from antibiotic-associated diarrhea to fulminant colitis, which are often acquired in hospitals and are associated commonly with men exposed to surgery $[47,48]$. C. difficile is characterized by forming spores that survive in the acidic environment of the stomach lumen and by producing exotoxins when germination occurs in response to exposure to bile acids in the small bowel [47]. The fact that biliary secretions that act as spore germination inductors, such as taurocholate, also known as bile salt, share the fused ring structure with steroid hormones and that both are synthesized from cholesterol has suggested that steroid hormones should also regulate the germination of bacterial spores [49]. In this regard, the effects of progesterone and progesterone analogs such as pregnenolone as well as metabolic intermediates of estrogens such as dehydroepiandrosterone (DHEA) have been analyzed on $C$. difficile spore germination. Some of these steroids inhibit spore germination (progesterone showed a half maximal effective concentration of $80.5 \mu \mathrm{M}$ and DHEA of $168.3 \mu \mathrm{M}$ ), acting as competitive inhibitors of taurocholate, suggesting an important role of progesterone and estradiol to the resolution of infection caused by $C$. difficile [50].

A sexual dimorphism has also been reported in the disease produced by Yersinia enterocolitica. Yersiniosis is a zoonotic disease transmitted by domestic animals, mainly by pigs, as well as contaminated pork products or water. $Y$. enterocolitica infection provokes enteritis, enterocolitis, and gastroenterocolitis, which symptoms include bloody diarrhea, fever, abdominal pain, and vomiting; chronic cases of infection develop necrotic enteritis and purulent mesenteric lymphadenitis [51]. Yersiniosis is more recurrent in male patients of diverse ages (mainly children) than in females, and this tendency has been reported in an epidemiological study performed in Germany [52]. To our knowledge, there are no studies about the gender-associated molecular mechanism involved in the course of infection by $Y$. enterocolitica; nevertheless, there are higher serum levels of IgG4 antibodies in male patients as compared with female patients in response to Yersinia outer membrane proteins (Yops) [53], which are plasmid-encoded virulence factors secreted by a type III secretion system [51]; however, researchers did not provide an explanation to this result [53]. In the same regard, it has been reported that high levels of IgG4 are related with chronic exposure to antigen [54], which in turn is associated to an excessive activation of anti-inflammatory mechanisms that can be related with a resistance to treatment in males as it has been observed in other infections [55, 56]. Thus, IgG4 levels in males during $Y$. enterocolitica infections can be associated with an anti-inflammatory response that interferes with the disease outcome.

Vibrio spp. are marine and estuarine bacteria that cause infections from gastroenteritis to wound infections, also with a higher prevalence in males. The gastric infections by Vibrio spp. are associated with seafood consumption, principally raw oyster ingestion. Vibrio species that commonly causes gastroenteritis are Vibrio parahaemolyticus. $V$. cholerae, $V$. hollisae, $V$. mimicus, and $V$. fluvialis, infections with a reported male-female incidence ratio of 1.7:1 [57]. $V$. cholerae is the most representative species in the genus, with the highest proportion of cases of Vibrio-associated gastroenteritis (71\%), their toxigenic strains belonging to O-group (mainly serogroups O1 and O139) are the cause of epidemic cholera, with 2.86 million cases and 95,000 deaths annually $[57,58]$. In spite of the evident male prevalence, the molecular mechanism involved in the gender bias in Vibrio infections, particularly the role played by sexual hormones, has not been studied.

In contrast to the aforementioned gastrointestinal infections, enterohemorrhagic Escherichia coli (EHEC) O157 infections are more frequent in female individuals, with $61 \%$ of the adult cases from 2000 to 2009 in the Japanese 
population [59]. In another study performed in an Asian population, comparable prevalence rates for females were found since $54.3 \%$ cases in Korea and 53.7\% in Japan were women [60]. A similar pattern was observed during an outbreak of enteroaggregative Shiga-toxin E. coli O104:H4 in Germany in 2011, where most of the infected people were women, corresponding to $58 \%$ of infected adults; furthermore, the frequency of women who developed the concomitant hemolytic-uremic syndrome was greater than men [61]. Sequels of these infections are also more frequent in female than in male patients, such as irritable bowel syndrome (IBS), a chronic disorder that causes symptoms as cramping, pain, bloating, flatulence, nausea, diarrhea, and constipation $[62,63]$. In turn, aggravation of IB is associated with alterations of gastrointestinal physiology due to varying levels of sex steroid hormones throughout the menstrual cycle and to the activity of these hormones through their cognate receptors located in the gastrointestinal tract [64]. For example, low estradiol during menstruation causes intestinal inflammation by inducing mast cell degranulation and prostaglandin production that in turn are associated with visceral sensitivity and could exacerbate the response to infections $[64,65]$.

In general, sex dimorphism in gastrointestinal infections tends to favor a successful outcome in women, through the actions of estradiol via its intracellular receptors, which, as in other infections, regulate immune system function as well as host non-immune factors and bacterial physiology. In contrast, some infections, such as that caused by EHEC are affected by cyclic changes in female hormone levels, provoking worse outcomes in women. However, differential regulation of immune system in response to specific concentration of female hormones can be an advantage in the treatment of gastric infections.

\section{Bacterial infections in the respiratory tract}

In general, males are more susceptible than females to lung diseases such as neonatal respiratory distress syndrome, pulmonary arterial hypertension, idiopathic pulmonary fibrosis, and asthma, and this is also observed for community-acquired and nosocomial bacterial pneumonia, in which severity and higher risk for mortality are associated with male patients [66-69]. In fact, it has been suggested that male sex is a frequent risk factor and a predictor of worse outcome for most of the respiratory tract infections, with exception of some upper respiratory tract infections (sinusitis, tonsillitis, and otitis externa) that are more frequently found in females [67]. As in other infections, the sexual dimorphism in respiratory infections has also been attributed, independently of sex hormones and genetic factors, to socioeconomic, lifestyle, behavioral, and other factors [70-72] that will not be considered in the present review. In women, these differences have been mainly attributed to a gender inequality in work and access to healthcare system [67]. Interestingly, it has been reported that there are no significant differences between the immune response of men and women athletes that could be associated with respiratory tract infection incidence, suggesting that in this population there is no sexual dimorphism [73].

It has been reported that biological factors could also contribute to the sexual dimorphism observed in respiratory tract infections, such as anatomical and physiological differences in the respiratory tract [67]. In women, the higher prevalence of rhinosinusitis could be due to the fact that they have smaller ostia than men, which is more frequently associated with obstruction and therefore with infection [74]. In contrast, it has been suggested that the higher prevalence of lower respiratory tract infections in boys during the early years of life is due to peripheral airway width disproportions that are more marked in males [75].

The effects of sexual hormones on the immune response of the respiratory tract depend on the experimental model. It has been demonstrated that estradiol induces an increase in inflammatory cytokines (such as TNF- $\alpha$ and IL-6) and chemokines (such as monocyte chemoattractant protein 1 and macrophage inhibitory protein $1 \alpha$ ) in the lungs of ovariectomized mice infected with Pseudomonas aeruginosa, which in turn is associated with a neutrophil dysfunction and a worst outcome as compared with vehicle-treated female mice and intact males. Interestingly, this effect was ER dependent [76]. In contrast, in an experimental model of pleurisy (pleural inflammation) in ovariectomized rats, estradiol treatment prior to the inflammatory insult was associated with a decrease in NO production, migration of polymorphonuclear cells, and tissue injury, which was also ER dependent [77]. Furthermore, it has been suggested that estradiol promotes an increase of IgA transport into the mucosa of the respiratory tract protecting against pneumonia [78]. More studies are required to elucidate the beneficial or detrimental effects of estradiol and other sexual hormones during respiratory tract inflammation.

The incidence of community-acquired pneumonia is higher in men than in women, and this incidence increases by age, especially in infections with Streptococcus pneumoniae, Streptococcus pyogenes, Chlamydophila pneumonia, and Legionella pneumophila [79-86]. On the other hand, a gender preference for pneumonia caused by drug-resistant pathogens such as $P$. aeruginosa, exten ded-spectrum-beta-lactamase-positive Enterobacteriaceae, and methicillin-resistant Staphylococcus aureus has not been established, as this gender preference depends on the studied population [87-89]. Females have a 57\% reduced 
risk to acquire ventilator-associated pneumonia after mechanical ventilation, which has been reported to affect $72.7 \%$ of males, mainly due to Gram-negative bacterial infections [90, 91]. In contrast, women under the age of 50 years are more susceptible to respiratory infections by Mycoplasma pneumoniae [92]. For a comprehensive and complete review of the incidence and severity in respiratory tract infections refer to [67].

Tuberculosis, caused by Mycobacterium tuberculosis, is one of the most studied models regarding sexual dimorphism in respiratory tract infections. In humans, tuberculosis is one of the leading causes of death from infectious diseases. It was diagnosed in about 8.6 million people in 2012, and it has been predicted that one third of the population in the world has a latent infection [93]. Some of the risk factors for tuberculosis infection are malnutrition, smoking, diabetes, and sex [94]. Although the prevalence of tuberculosis in males depends on the geographic region, there is a general trend for the male-to-female ratio affecting more males with poorer outcome in developing countries, including a higher risk of mortality [93, 95-100]. This male gender prevalence is also observed when combining other risk factors such as human immunodeficiency virus (HIV) infection, diabetes mellitus, and smoking [101-104]. It has been reported that Bacillus Calmette-Guerin (BCG) unvaccinated males display a stronger IFN- $\gamma$ response against the tuberculin purified protein derivative (PPD) than females, which suggests that males display a stronger immune response that could be associated with an uncontrolled inflammatory response and a poor prognosis during M. tuberculosis infection [105]. During tuberculosis infection, there is also a differential immune response characterized by females showing higher levels of the C-X-C Motif Chemokine Ligand 9 (CXCL9) and males showing higher levels of the Platelet Derived Growth Factor Subunit B (PDGFB), serum C-reactive protein, and specific antibodies against $M$. tuberculosis than their gender counterpart, highlighting a stronger innate and humoral immune response in males [106, 107]. Furthermore, the plasmatic levels of the anti-tuberculosis drugs, isoniazid, and pyrazinamide are lower in adult males than in females. This could be related to the worst outcome in the treated males [108]. Interestingly, this higher proportion of affected males is not observed in children or young adolescents, suggesting the participation of sex hormones in the pathogenesis of tuberculosis $[109,110]$. In line with this, it has been reported that the prevalence of tuberculosis associated deaths in a mentally retarded population was lower in medically castrated males (8.1\%) compared with intact males (20.6\%) and females (15.8\%) [111]. Women who underwent medical oophorectomy present an increased risk of mortality because of tuberculosis [112]. However, it has been also demonstrated that this male bias to tuberculosis infection is due to genetic factors, illustrated by X-linked TLR8 gene polymorphisms that have been associated with increased susceptibility to tuberculosis in male children [113], as well as by the X-linked Mendelian susceptibility to mycobacterial diseases due to mutations in IKBKG and CYBB genes, that participate in the induction of IL- 12 by mononuclear cells and the activation of the respiratory burst in macrophages, respectively [114]. Besides, it has been reported that elderly women with decreased estrogen levels (postmenopausal women) have an increased risk of chronic lung infections produced by nontuberculous Mycobacterium infections [115]. Particularly, it has been found that decreased DHEA (an endogenous intermediate in the conversion of cholesterol to estrogens and androgens) levels in elderly women are associated with M. avium complex infection, a nontuberculous mycobacterial lung infection [116]. These studies suggest that nontuberculous Mycobacterium infections are also influenced by hormones, which in turn explains the sexual dimorphism in overall Mycobacterium infections in the respiratory tract.

Animal models have been used to further investigate the role of sex hormones in the pathophysiology of tuberculosis. Early studies demonstrated that male mice are more susceptible than female mice to infection with $M$. intracellulare and $M$. marinum and that testosterone treatment increases female and castrated male mice susceptibility to $M$. marinum showing more severe granulomatous lung lesions, contrary to the protective effect observed after estradiol treatment in ovariectomized mice exposed to M. avium [117-119]. Sex bias has also been reported in $M$. tuberculosis mice infection, where male mice are at greater risk of mortality and show higher numbers of bacilli burdens in lungs with a lower pro-inflammatory response (constituted mainly by decreased levels of lymphocytes, macrophages, and expression of pro-inflammatory cytokines) than female mice and castrated mice [120]. Interestingly, it has been demonstrated that medroxyprogesterone acetate (DMPA), a progestin commonly used as a contraceptive, decreases the cytokine response to M. tuberculosis in C57BL/6 and BALB/c mice [121].

Regarding other animal models, it has been reported that bovine tuberculosis caused by $M$. bovis also displays a worse outcome, higher mortality rate, and more rapid progression rates in males than in females, and this difference has been attributed to an immunosuppression induced by testosterone in males [122-124]. The above studies clearly demonstrate a sexual dimorphism in Mycobacterium spp. respiratory tract infections affecting 
more males than females, which is influenced by estradiol and testosterone and the genetic background. The participation of sex hormone receptors in this dimorphism has not been elucidated.

In the natural model of murine respiratory mycoplasmosis induced by $M$. pulmonis, it has been demonstrated that male mice display a more severe clinical outcome than females, with higher rates of mortality and worse signs of alveolar disease, but in contrast to other mycoplasmosis, the removal of gonads decreases the severity of lung injury and bacilli number in both sexes [125]. Interestingly, in this study, sex differences in M. pulmonis infection were remarkable since male mice showed an acute alveolar inflammatory response (edema, hemorrhage, and neutrophil infiltrate) whereas female mice showed a chronic peribronchial inflammatory response (macrophage and few neutrophil infiltrates), which explains the worse outcome in males [125].

Legionnaires' disease is a severe form of infection with Legionella species, which are Gram-negative bacteria that are ubiquitously found in natural and artificial aquatic habitats, as well as in moist soil and mud $[126,127]$. Legionellosis is mainly characterized by pneumonia with a high incidence of mortality rates, and although it is frequently observed as sporadic cases, it has been also reported in community and hospital outbreaks mainly due to contamination in the air conditioning systems [128-130]. It has been reported a strong association of legionellosis with male gender in many European, American, and Asian countries, as well as in Australia, and in fact, male gender is considered as a poor prognostic factor [131-141].

In contrast to the mentioned respiratory tract infections, there are bacterial infections that affect more females than males. These gender differences have been clearly demonstrated in cystic fibrosis disease (CF) that is characterized by a dysregulated inflammatory response and an altered cytokine profile in the lungs that is associated with a higher prevalence of bacterial infections (mainly due to $P$. aeruginosa) and poorer lung and respiratory muscle function in females than in males [142-144]. Differential estradiol levels between females and males have been proposed as a factor that explains the sexual dimorphism in CF-associated infections because differences in gender lung function are observed after puberty and are correlated with estrogen levels during the menstrual cycle [145]. In particular, high estradiol levels in CF females have been associated with the conversion of $P$. aeruginosa in a highly pathogenic mucoid bacteria that induces parenchymal damage in the lung [146]. Moreover, the increase in estradiol levels in $\mathrm{CF}$ females upregulates the expression of the secretory leucoprotease inhibitor via ER- $\beta$, that in turn inhibits the TLR-dependent IL-8 release in CF bronchial epithelial cells predisposing to $P$. aeruginosa infection and colonization [147]. It has been demonstrated that $P$. aeruginosa pulmonary infection is also associated with a worse outcome in female mice, which is characterized by a more pronounced weight loss, higher numbers in bacterial load, and a higher inflammatory response than those observed in male mice [148]. It has been also reported that female sex is associated with an increase in the mortality rate in a model of CF mice with $P$. aeruginosa pulmonary infection [149]. Furthermore, estradiol administration increases the severity of $P$. aeruginosa pneumonia in adult CF male mice by upregulating IL-17 signaling and promoting lung tissue damage [150].

Interestingly, it has been reported that perinatal pulmonary infection induced by the intracellular bacteria Chlamydia muridarum displays a sexual dimorphism in terms of hippocampal expression of corticosteroid receptors associated with an altered stress response that emerges during adulthood, in which females are more affected by neonatal infection than males as demonstrated by an increase in glucocorticoid receptor and tyrosine hydroxylase content in adulthood, that in turn leads to a dysregulation of the hypothalamic-pituitary-adrenal axis [151]. This highlights the importance of the sexual dimorphism in bacterial infections not only in the affected tissue but also in other organs such as the brain.

There are epidemiological studies reporting that air pollution confers a higher susceptibility to respiratory tract diseases to females as compared with males [152-154]. Although there are some controversies about this prevalence in humans, studies in mice have demonstrated that after ozone-induced oxidative stress, there is a decrease in survival rate that is more pronounced in female than in male mice in Klebsiella pneumoniae lung infection, which is in contrast to the lower survival rate observed in male mice in ozone-free conditions. These differences have been associated with a compromised spleen, reduction in functional activity of surfactant protein $\mathrm{A}$, increased plasma cortisol levels, and reduced phagocytic ability of alveolar macrophages in ozone-exposed female mice [155-157]. Ozone exposure alone is associated with an increased inflammatory response, higher lung vascular permeability, and higher number of polymorphonuclear neutrophils in bronchoalveolar lavage in female mice [158]. Interestingly, it has been proposed that female gonadal hormones (estradiol and progesterone) are protective against $K$. pneumoniae pulmonary infection; however, the protective effect is lost after ozone exposure, and even leads to a worse outcome that could be related to the excessive activation of the inflammatory pathway in response to estradiol and ozone exposure [159].

Although there is an evident sexual dimorphism in both humans and animal models of respiratory tract infections, the participation of hormone receptors has been poorly explored. The fact that estradiol and testosterone have 
been proposed to participate in the pathogenesis of the mentioned respiratory tract infections strongly suggests that intracellular and/or membrane hormone receptors are involved in this sexual dimorphism. One example is the participation of ER- $\beta$ in the inhibition of TLR dependent IL-8 release in CF bronchial epithelial cells in the model of CF mice infected with $P$. aeruginosa, which clearly demonstrates an important role of hormone receptors in the gender bias of $P$. aeruginosa induced pneumonia [147]. Therefore, further studies are required to elucidate the participation of hormone receptors in the sexual dimorphism observed in bacterial infections in the respiratory tract that in turn could help in prognosis and management.

\section{Sexual dimorphism and bacterial sepsis Sepsis}

The host response against a bacterial infection that leads to a systemic inflammatory response syndrome is defined as sepsis, which is characterized by the increase in TNF- $\alpha$, IL- $1 \beta$, IL- 6 , and IL- 8 cytokine secretion mainly by macrophages after the recognition of bacteria or bacterial-derived lipopolysaccharide (LPS) via TLRs [21, 160]. Although there are some controversies about the sex-specific response in sepsis patients [161], it has been stated that gender plays a significant role in post-injury pathogenesis and its association with the susceptibility to sepsis by affecting more males than females $[162,163]$. This gender bias is explained only in part because of occupational, hygiene, and sport activities differences among men and women [164]. In fact, male gender is considered as one of the four risk factors associated with the development of sepsis in general surgical and post-traumatic patients, with a hospital mortality rate of $70 \%$ in male and $26 \%$ in female patients $[18,165,166]$. Moreover, it has been reported that male gender along with HIV infection is a risk factor for bacteremia, suggesting an important role of immune suppression [167]. The pathological response to trauma-hemorrhage in rodent males, ovariectomized females, and testosterone-treated females is characterized by a severe suppression of the immune response and multiple organ dysfunctions, leading to a high incidence of sepsis [168-170]. Interestingly, these effects are not observed in proestrus rats, estradiol-treated ovariectomized rodents, castrated male rodents, and estrogen-treat ed males, which clearly point out the participation of estradiol and testosterone in the sex bias of sepsis after trauma-hemorrhage $[168,171,172]$.

Moreover, a differential immune response between genders during sepsis has been observed and is characterized by a specific profile of pro- and anti-inflammatory cytokines. In particular, male patients display higher levels of pro-inflammatory cytokines such as IL-6 and TNF- $\alpha$ as well as increased levels of bacteremia markers like procalcitonin in sepsis than females [173-176]. In contrast, female patients display higher levels of the anti-inflammatory cytokine IL-10 than males [18]. These differences between immune responses before and after trauma-hemorrhage leading to sepsis suggest that females display an early and controlled pro-inflammatory response that prevents infection which is followed by an anti-inflammatory response that avoids systemic damage, while males display a late and persistent active pro-inflammatory response leading to systemic damage. Besides, the fact that sexual dimorphism in severe sepsis is also observed in prepubertal children and elderly people suggests that genetic and environmental factors are also involved in this gender bias [177-179].

\section{Experimental sepsis}

Animal models have been widely used to study sex differences in regard to immune response and clinical effects of sepsis. In particular, cecal ligation and puncture (CLP) in mice, leading to polymicrobial sepsis, has demonstrated that proestrus female mice display a higher survival rate than male mice, along with a marked increase in splenocyte proliferation and IL-2/IL-3 release as compared with male mice, suggesting that immune homeostasis regulation is better regulated in females than in males [180]. Remarkably, beta-glucan therapy promotes survival in mice subjected to CLP and displays a better protective effect in female than in male mice by enhancing bacterial clearance, which is dependent on sex hormones [181]. The use of estradiol or DHEA in male mice subjected to CLP improves splenocyte, macrophage, and $\mathrm{T}$ cell activity $[182,183]$. Sex differences favoring female mice after CLP are similar to the better prognosis observed in female patients undergoing major abdominal surgery; in these cases, male patients present decreased numbers of circulating $\mathrm{B}$ and $\mathrm{T}$ lymphocytes and NK cells after abdominal surgical intervention [184]. It has been proposed that sex differences in prognosis after abdominal trauma and subsequent sepsis are due to an enhanced and strictly regulated antimicrobial host defense in the female peritoneum as compared with that of males, which in females, is characterized by a higher number of quiescent leukocytes (mainly $\mathrm{T}$ and B lymphocytes), competent resident macrophages (that highly express TLRs and display elevated phagocytosis), and immunomodulatory CD4 lymphocytes $[11,36]$. Furthermore, estradiol and progesterone are necessary to maintain homeostasis regulation of resident leukocytes in the female peritoneum, while testosterone disrupts the trigger of an appropriate innate immune response against polymicrobial insult $[36,185]$.

Another sepsis model in animals is the "two-hit" model that consists in trauma-hemorrhage-induced shock (first hit) and subsequent sepsis (second hit), in which females display a better outcome and survival than males, presenting lower plasma levels of pro-inflammatory markers (IL-6, 
TNF- $\alpha$, and prostaglandin E(2)) after sepsis [186]. However, a recent study failed to find a correlation between inflammatory markers and the different outcome observed in female and male mice in the "two-hit" model [187]. A protective effect has been observed in proestrus rat during hemorrhagic shock as compared with other estrous cycle phases; this has been attributed to the highest levels of estradiol in proestrus phase [188]. Protective effects of estradiol against sepsis following hemorrhagic shock have been reported in trauma-hemorrhage-induced lung and hepatic injury by decreasing the TLR4-dependent release of pro-inflammatory cytokines (IL-6, TNF- $\alpha$, and macrophage inflammatory proteins $1 \alpha$ and 2) and chemokines (monocyte chemoattractant protein-1 and keratinocyte-derived chemokine), as well as the induction of the inducible nitric oxide synthase (iNOS) expression, neutrophil influx, and tissue damage [189-191]. On the other hand, higher levels of testosterone and its derivatives (such as 5 $\alpha$-dihy drotestosterone, DHT) are associated with negative effects during trauma-hemorrhage that are associated to immunosuppression and subsequent sepsis in mice. In particular, DHT has been implicated in the decrease of splenocyte proliferation; macrophage function; decline of IL-1, IL-2, IL-3, IL-6, and IFN- $\gamma$ release by splenocytes and peritoneal macrophages; and a marked increase of IL-10 levels [170, 192, 193]. In addition, it has been reported that testosterone downregulates the expression of the major histocompatibility complex (MHC) class II receptor on splenic and peritoneal macrophages after trauma-hemorrhage, reinforcing immune suppression [194]. The role of testosterone in the suppression of the immune system in the sepsis model has been confirmed by using the antagonist of the AR, flutamide that in turn improves survival and organ function in male mice $[195,196]$.

In vitro studies have shown that after LPS exposure, TNF- $\alpha$ levels are lower in peripheral blood cells isolated from premenopausal women than those from men and postmenopausal women; however, this was not associated to estradiol or testosterone levels in premenopausal women [197]. In addition, it has been reported that estradiol and LPS treatments in peripheral blood mononuclear cells isolated from women and men healthy volunteers induce the secretion of TNF- $\alpha$ and IL-6, while estradiol and LPS treatments decrease IL-10 secretion only in male sepsis patients, which suggests that the worst prognosis in males after sepsis is associated with a non-regulated immune response [198]. More studies are required in order to elucidate the role of IL-10 in sepsis affecting males since the increased levels of this cytokine are associated with a worse outcome by exerting suppression in the immune response, whereas its reduction leads to a non-controlled pro-inflammatory response. Interestingly, both effects are dependent on sex hormones.
One of the most used models to simulate bacteremia is LPS injection into bloodstream, which is known as experimental endotoxemia. Although there are controversies about the mechanisms involved in the sexual dimorphism of LPS response, it is accepted that males are more affected than females in LPS-induced endotoxemia [199, 200]. It has been reported in mice and rat models that males and ovariectomized females show higher levels of IL-6- and LPS-binding protein (LBP, that promotes a pro-inflammatory cellular response) after LPS-induced endotoxemia [20,201]. An increase in visfatin expression levels (an adipokine with pro-inflammatory properties) has been reported in the serum, liver, and adipose tissue from male and female rats after LPS-induced endotoxemia, and this increase is higher in the adipose tissue of ovariectomized rats that also display a worse outcome and higher levels of mortality than intact animals [202, 203]. In contrast, it has been reported that male rats display an early suppressive immune response (decreased levels of TNF- $\alpha$ as compared with females) after LPS injection that is testosterone dependent, confirming an increased susceptibility to sepsis in males as compared with females [204]. Furthermore, an acute pro-inflammatory response characterized by a higher increase in TNF- $\alpha$ levels in female than in male calves was observed after LPS treatment, which was associated to a better outcome in females [205]. In line with this, women show a higher pro-inflammatory innate immune response during experimental endotoxemia than men, as revealed by a higher leukocyte sequestration, greater levels of the pro-inflam matory cytokine TNF- $\alpha$, and increased levels of the LBP without changes in the anti-inflammatory cytokine IL-10 [206]. Further studies are required to overcome controversies in the elucidation of the molecular differences involved in gender bias after LPS-induced endotoxemia.

Although a marked sexual dimorphism in favor of females is observed in the development of sepsis, it has been proposed that in some cases females display a higher risk than males to severe shock once sepsis has occurred. This is the case of the superantigen toxic shock affecting more women than men, which has been associated with menstrual infections [207]. Superantigens are known as potent $\mathrm{T}$ cell activators that bind to the class II MHC and T cell receptors [208]. Therefore, a toxic shock is produced by the superantigen-induced $\mathrm{T}$ cell hyperactivation that leads to an increase of plasma pro-inflammatory cytokines (IL-1, TNF- $\alpha$, TNF- $\beta$, and IFN- $\gamma$ ), profound hypotension, and multiorgan failure [208-210]. Despite the fact that superantigen toxic shock gender bias could be explained by its relation to menstrual-associated infections, it has also been demonstrated that female mice are more sensitive than males to superantigen-mediated toxic shock, which is associated with an ER-dependent increase in plasma TNF- $\alpha$ levels, liver damage, and lower survival in female mice, 
confirming the role of sex hormones in sexual differences of superantigen toxic shock [211]. This is also true for animal models in which the gender bias is influenced by the specific model of study and bacteria. In particular, estradiol administration prevents bacteremia in ovariectomized rats intraperitoneally inoculated with Enterococcus faecalis by increasing TNF- $\alpha$ and NO levels [212]. Male mice are more susceptible to Streptococcus pneumoniae intravenous administration than females by showing higher mortality rate, weight loss, and body temperature decrease, along with an increase in blood pro-inflammatory cytokines such as IL-6, IL-17A, RANTES, and IFN- $\gamma$ as compared with female mice [81]. On the other hand, Listeria monocytogenes systemic infection is more prevalent in female mice due to the estrogen downregulation of IFN- $\gamma$ and IL-10 induction that leads to an immune suppression [213].

\section{Genetic-dependent effects}

Interestingly, it has been demonstrated that female $\mathrm{X}$ chromosome mosaicism (due to $\mathrm{X}$ random inactivation) provides an expanded repertoire of immune functions in females as compared with males [214]. Since a large number of genes related to immune functions are located on the $\mathrm{X}$ chromosome, X-linked mosaicism confers a highly polymorphic gene expression program that is specific to different cell subpopulations which respond differently to particular immune challenges [215]. It has been reported that mosaic mice with a heterozygous deficiency of the $\mathrm{X}$-linked Nox2 gene (that encodes the catalytic subunit of the NADPH oxidase complex in phagocytes) displays a clear advantage during CLP as compared with wild-type animals, which is characterized by lower plasma IL-6 levels, reduced oxidative stress, higher bacterial clearance and improved survival, highlighting the contribution of genetic factors in the sexual dimorphism during sepsis [214]. This finding was further confirmed in a similar model with a heterozygous deficiency of the X-linked Irak1 gene (involved in the activation of the innate immune response) that displays better survival, lower plasma IL-6 and IL-10 levels, and non-altered splenic $B$ and $T$ cell populations as compared with wild-type animals in a CLP model [216]. Furthermore, it has been reported that mesenchymal stem cells obtained from female mice display a greater protective effect of myocardial function than those derived from male mice in a model of endotoxemia, confirming that genetic factors are also responsible for the gender bias in sepsis [217].

It has been suggested that a dimorphic expression of TLR4 is associated with a differential immune response between males and females [218]. In particular, higher levels of TLR4 expression in macrophages from male mice have been associated with a damaging and uncontrolled pro-inflammatory response following endotoxic shock induced by LPS administration [20]. More studies are required to demonstrate the sexual dimorphism in TLR4 expression since another study failed to find this differential expression between macrophages from male and female mice [219]. Although there is a clear prevalence of sepsis in males, sexual dimorphism does not always favor females since it depends on the population evaluated as well as on the bacterial species (Table 2). Interestingly, the differences

Table 2 Gender preference in sepsis induced by specific bacterial species

\begin{tabular}{|c|c|c|c|}
\hline Bacteria species & $\begin{array}{l}\text { Gender } \\
\text { preference }\end{array}$ & Population & References \\
\hline \multirow[t]{2}{*}{ Staphylococcus aureus } & Women & Israel & [250] \\
\hline & Men & United States of America & [251] \\
\hline \multirow{4}{*}{$\begin{array}{l}\text { Staphylococcus aureus } \\
\text { (methicillin resistant) }\end{array}$} & Women & Brazil & [252] \\
\hline & No differences & United Kingdom & [253] \\
\hline & Women & $\begin{array}{l}\text { United States of America } \\
\text { (hemodialysis patients) }\end{array}$ & [254] \\
\hline & Men & $\begin{array}{l}\text { Australia, Sweden, Denmark, } \\
\text { Germany, Spain, United Kingdom, } \\
\text { United States of America }\end{array}$ & {$[255-258]$} \\
\hline Salmonella enterica (non-typhoidal) & Men & $\begin{array}{l}\text { Six regions in Finland, Australia, } \\
\text { Denmark, and Canada }\end{array}$ & [259] \\
\hline $\begin{array}{l}\text { Escherichia coli (extended-spectrum } \\
\beta \text {-lactamase-producing) }\end{array}$ & Women & Cancer patients & [260] \\
\hline Escherichia coli & Women & Denmark & [261] \\
\hline Klebsiella spp. & Men & Denmark & [262] \\
\hline Streptococcus milleri & Men & Canada & [263] \\
\hline Streptococcus spp. & Men & United States of America & [251] \\
\hline Aeromonas spp. & Men & $\begin{array}{l}\text { Spain (chronic liver disease } \\
\text { or neoplasm) }\end{array}$ & [264] \\
\hline
\end{tabular}


in gender susceptibility to bacteremia among different populations highlight the importance of genetic background in the sexual dimorphism and sepsis.

\section{Estrogen and androgen receptor-dependent effects}

The fact that sex hormones participate in the gender bias observed in sepsis strongly suggests the participation of their receptors during this process, particularly ERs [220]. It has been demonstrated that treatment with specific ER- $\alpha$ and ER- $\beta$ agonists, propyl pyrazole triol (PPT), and diarylpropiolnitrile (DPN), respectively, induce protective effects on intestinal microcirculation in both male and ovariectomized rats during sepsis, providing a plausible explanation of homeostasis regulation of resident leukocytes in the female peritoneum [221]. Interestingly, it has been reported that after trauma-hemorrhage, PPT inhibits the TNF- $\alpha$ and IL- 6 release by Kupffer cells and promotes their production in splenic macrophages probably by the MAPK signaling pathway, while DPN has the same effect on alveolar macrophages and peripheral blood mononuclear cells. In addition, IL-10 secretion was decreased by PPT on Kupffer cells and by DPN on peripheral blood mononuclear cells, suggesting a differential role of ER- $\alpha$ and ER- $\beta$ in the protective effect of estradiol after trauma-hemorrhage that also depends on the specific tissue compartment [222-224]. Furthermore, PPT administration prevents the splenic $\mathrm{T}$ cell suppression observed after trauma-hemorrhage by enhancing IL- 2 and IFN- $\gamma$ secretion via MAPK, NF- $\mathrm{kB}$, and AP-1 signaling pathways, while it inhibits NF- $\mathrm{KB}$ and AP-1 signaling pathways on Kupffer cells to decrease iNOS expression and prevent hepatic damage $[225,226]$. On the other hand, treatments with the ER- $\beta$ selective agonist, WAY-202196, exert a protective effect in both male and female rodents subjected to CLP by decreasing TNF- $\alpha$ and IL- 6 levels, reducing bacteremia, and maintaining intestinal integrity [227]. It has been recently reported that raloxifene, a selective ER modulator, reduces the effects of LPS-induced endotoxemia in ovariectomized rats via the induction of antioxidant and anti-inflammatory proteins such as heme oxygenase 1 (HO-1) and heat shock protein 70 (HSP70), respectively [203]. Further studies are required to elucidate the participation of other sex hormone receptors by using specific agonists and antagonists, such as in the case of flutamide, an AR antagonist that displays protective effects in sepsis models, as previously mentioned [228]. Moreover, the role of PRs during sepsis has not been assessed. The study of the participation of both membrane and intracellular hormone receptors would provide an extensive repertoire of pharmacological treatments to prevent or manage sepsis.

\section{Other bacterial diseases}

Among other diseases that display a sex-based predominance are urinary tract infections (UTIs), which are present in females more often than in males [229]. UTIs in women occur more frequently than in men due to anatomical and physiological differences; for example, the urethra is shorter than that of men, and the distance between the anus and urethral meatus is also shorter in women. Additionally, the perimeatal region has less humidity in men than in women and prostatic secretions show antibacterial activity [230]; therefore, the probability of bacterial colonization and development of infection is lower in men. Seventy percent of these infections are related to $E$. coli strains. It has been reported that $65 \%$ of hospitalized elderly patients with UTI that have developed sepsis are women, similarly to the $54.8 \%$ of cases with a fatal outcome that has been documented in women [229]. Menopause is one of the risk factors of UTIs mainly due to the reduction of sex hormone levels, predominantly estrogens. When estrogen levels are low, as in postmenopausal woman, urogenital colonization of lactobacilli is decreased, which in turn produce a $\mathrm{pH}$ rise that allows the growth of Enterobacteriaceae, particularly E. coli [231].

Lyme borreliosis, a vector-borne inflammatory disease produced by Borrelia burgdorferi, is more common in women in the European population, frequently older than 44 years with recurrent infection and previously diagnosed with erythema migrans, the cutaneous manifestation of the infection. In contrast with men, women show an increased secretion of cytokines IFN- $\gamma$, IL-4, IL-6, IL-10, and TNF- $\alpha$. In addition, elevated ratios of IL-10/TNF $\alpha$ and IL-4/IFN- $\gamma$ have been observed in postmenopausal women, suggesting increased anti-inflammatory and Th2-based immune responses, while pro-inflammatory activity is reduced, which could explain the prevalence and recurrence of B. burgdorferi in this population [232]. Neurological form of disease, Lyme neuroborreliosis, is also common in female patients, mainly in girls, who usually present facial nerve palsy; in contrast, it is suggested that boys have a stronger immune response than girls during $B$. burgdorferi infection since boys have a higher level of cerebrospinal fluid inflammation (pleocytosis) [233]. It is suggested that during infancy males have a stronger innate immunity compared with females, presenting higher counts of basophils, monocytes, NKs, and higher levels of inflammatory mediators than females, as it has been reported after stimulation with LPS or mitogens [33]. Contradictory findings in Lyme borreliosis also can be related with differences in sex hormonal levels between women and men, children and adults, and variations through menstrual cycle and menopause, which can differentially influence the immune system function.

Sexually transmitted infections also have female predominance; as it is the case of infections of the genital tract caused by Chlamydia trachomatis and Neisseria gonorrhoeae. 
Susceptibility to both diseases is related to estradiol and progesterone levels, which throughout the menstrual cycle regulate the differential recruitment and function of immune cells and other components of the immune system [25, 234, 235]. An example of the influence of estrogens in C. trachomatis infection is observed when infected HeLa cells are treated with $17-\beta$-estradiol or with diethylstilbesterol (a synthetic estrogen analog), enhancing the adherence, growth, and elementary body formation of this bacterium [236]. Moreover, $\beta$-estradiol levels present an inverse correlation with the cervical concentration of cytokines IL-1 $\beta$, IL- 6 and IL-10 during primary chlamydial infections. Progesterone also presents a negative correlation with IL-1 $\beta$ in women with recurrent infections [237]. High estrogen levels also influence the susceptibility of females to gonococcal infection since $N$. gonorrhoeae-infected mice treated with $17 \beta$-estradiol developed bacteremia quickly, due to the effect of estradiol on the levels and function of polymorphonuclear leukocytes, that become unable to eliminate gonococci [238]. Besides, high levels of progesterone, such as those observed during the luteal phase of the menstrual cycle, also promote gonococcal infection in human cervical epithelial cells through the increase of Akt kinase activity, which in turn increases NOS expression and NO production, favoring the N. gonorrhoeae survival and replication [239].

Listeria monocytogenes infection is a disease acquired by contaminated food ingestion; however, the infection reaches the spleen, the liver, and the bloodstream causing bacteremia and, in some cases, reaches the brain producing meningitis [240]. Listeriosis predominantly affects females, and it has been mainly attributed to increased levels of IL-10, which has been observed in infected female mice that also show elevated bacterial counts in the liver and spleen, as well as higher rates of mortality than males. IL-10 acts as an immunosuppressor, by inhibiting Th1 differentiation and synthesis of Th1 cytokines, as well as by suppressing macrophage effector function, antigen presentation, and proliferation of $\mathrm{T}$ cells. On the contrary, infected male mice have elevated levels of IFN- $\gamma$ that helps to the resolution of disease, contributing to male-resistance to Listeriosis [241]. It has been observed that estrogen action influences female predisposition to Listeriosis by modulating the immune response to infection. When Listeria-infected mice are treated with $\beta$-estradiol, there is a reduction of monocytes and leukocytes at the infection site, and cells obtained from peritoneal exudates have an increased expression of IL-4, IL-10, and transforming growth factor- $\beta$ (TGF- $\beta$ ), while IFN- $\gamma$, IL-12, and TNF- $\alpha$ expression is decreased, which in turn is related to a suppression of bactericidal activity and to a shift of Th1 to Th2-response [242].
On the contrary, infection produced by Coxiella burnetii, known as $\mathrm{Q}$ fever, is a disease that preponderantly affects males. Patients with $\mathrm{Q}$ fever present diverse symptoms such as fever, granulomatous hepatitis, myocarditis, pericarditis, and pneumonia, which occur more frequently in men. Ovariectomized mice infected with $C$. burnetti and treated with $17 \beta$-estradiol display reduced spleen bacterial load and granuloma, suggesting that sexual dimorphism in C. burnetti infection is linked to sex hormones action [243]. Variations in the infection with $C$. burnetti between male and female mice are associated with differential gene expression programs. For example, in male mice, an upregulation of IL-10 and IFN- $\gamma$ genes has been observed, while genes that encode defensins were downregulated, increasing bacterial proliferation. On the other hand, in female mice, there are changes in the regulation of genes involved in circadian rhythm, that are related to estrogens secretion and IFN- $\gamma$ production, which in turn are possibly associated with the successful control of infection [244].

Wound infections caused by marine bacteria also display male predominance, such as the case of $M$. marinum, an aquatic bacterium that produces the swimming-pool granuloma or fish-tank granuloma disease, which progresses in necrotizing lesions that in some cases reaches tendons and bones [245]. Marine bacteria of Vibrio genera that produce infections in skin lesions are represented by $V$. vulnificus, $V$. alginolyticus, $V$. parahaemolyticus, and non-O1 $V$. cholerae. Wound infections by Vibrio spp. mainly occur in men over 50 years of age with a preexisting lesion that is exposed to contaminated seawater or seafood, developing edema, cellulitis, vesicles, and necrosis $[245,246]$. The low frequency of these infections in women has been associated with a protective role of estrogens against the endotoxins of $V$. vulnificus [200, 245].

Also, periodontal infections show sexual dimorphism, for instance, men are more susceptible than women to develop periodontitis, which as other infections are mainly attributed to the elevated production of pro-inflammatory cytokines in response to differential gene regulation through the action of sex steroid hormones [247]. In this respect, Cotti and others found that patients with endodontic infection (apical periodontitis) have increased levels of cytokine IL-2; however, these levels are considerably more elevated in men than in women [248]. In addition to IL-2, male patients present elevated levels of other inflammatory markers such as IL-1, IL-6, and asymmetrical dimethylarginine (ADMA, the inhibitor of NOS), as well as IgA, IgG, and IgM [248, 249]. Interestingly, chronic periodontal inflammation is considered a cause of endothelial dysfunction by inducing reactive oxygen species production in response to NO synthesis inhibition by ADMA, that in turn contributes to the development of cardiovascular diseases, which are more frequent in men than in women [248]. 
As it has been exposed in other sections of this review, gender prevalence in diverse bacterial infections is mainly associated to differential sex-linked immune responses regulated by sex hormones. However, host metabolic pathways, as well as expression and activity of bacterial virulence factors, are also affected by hormone action, which can influence the development of adverse sequels of infections that also show gender-associated predominance (Table 1).

\section{Conclusions}

Sexual dimorphism in bacterial infections is attributed to socioeconomic, lifestyle, behavioral, and biological factors. The latter was reviewed in the present study and is represented by genetic factors and sex steroid hormone levels and their actions in the host, as well as by the specific bacterial species that produce infection. In general, males are more susceptible to gastrointestinal and respiratory bacterial diseases and sepsis, while females are more susceptible to urinary tract bacterial infections; however, there are conflicting data regarding other specific bacterial diseases. Sexual dimorphism is in part explained by the pro-inflammatory properties of estradiol and by the anti-inflammatory effects of testosterone via the interaction with their specific intracellular receptors. However, the participation of other hormone receptors such as PR and other membrane or intracellular receptors in the gender bias of bacterial infections has not been elucidated. Interestingly, female X chromosome mosaicism provides an advantage to females due to the expanded repertoire of immune functions. Further studies are required to clarify contradictory data and to elucidate the molecular pathways of sex steroid hormone actions involved in the gender bias of bacterial infections in order to use sex hormones, their synthesis pathways, and their receptors as possible host-directed therapeutic targets.

\section{Abbreviations \\ ADMA: Asymmetrical dimethylarginine; AR: Androgen receptor; CF: Cystic fibrosis; CLP: Cecal ligation and puncture; DHEA: Dehydroepiandrosterone; DHT: 5a-dihydrotestosterone; DMPA: Medroxyprogesterone acetate: EHEC: Enterohemorrhagic Escherichia coli; ER: Estrogen receptor; HIV: Human immunodeficiency virus; IBS: Irritable bowel syndrome; IFN: Interferon; Ig: Immunoglobulin; L: Interleukin; iNOS: Inducible nitric oxide synthase; LBP: LPS-binding protein; LPS: Lipopolysaccharide; MHC: Major histocompatibility complex; NK: Natural killer; NO: Nitric oxide; PR: Progesterone receptor; TGF: Transforming growth factor; TIP: Typhoid ileal perforation; TLR: Toll-like receptor; TNF: Tumor necrosis factor}

\section{Acknowledgements}

EGG thanks CONACYT for the assigned Cathedra (project 899). The authors acknowledge Dra. Norma Espinosa Sánchez for critical comments on the manuscript.

\section{Funding}

Work in our groups is supported by grants from Dirección General de Asuntos del Personal Académico, UNAM (IN209617) to B. González-Pedrajo and from Programa de Apoyo a la Investigación y al Posgrado, Facultad de Química, UNAM (5000-9107) to I. Camacho-Arroyo.

\section{Authors' contributions}

ERVM and EGG participated in the writing of the manuscript. ICA and BGP conceived the review and participated in the design, revision, and writing of the manuscript. All authors read and approved the final manuscript.

Ethics approval and consent to participate

Not applicable.

Consent for publication

Not applicable.

Competing interests

The authors declare that they have no competing interests.

\section{Publisher's Note}

Springer Nature remains neutral with regard to jurisdictional claims in published maps and institutional affiliations.

\section{Author details}

${ }^{1}$ Unidad de Investigación en Reproducción Humana, Instituto Nacional de Perinatología-Facultad de Química, Universidad Nacional Autónoma de México (UNAM), Ciudad de México, Mexico. ${ }^{2}$ Unidad de Investigación en Reproducción Humana, Consejo Nacional de Ciencia y Tecnología (CONACyT)-Instituto Nacional de Perinatología, Ciudad de México, Mexico. ${ }^{3}$ Departamento de Genética Molecular, Instituto de Fisiología Celular, UNAM, Ciudad Universitaria, Av. Universidad 3000, Coyoacán, 04510 Ciudad de México, Mexico.

Received: 23 February 2018 Accepted: 8 June 2018

Published online: 20 June 2018

\section{References}

1. Rettew JA, Marriot I, Huett YM. Sex differences in innate immune responses to bacterial pathogens. In: Klein SL, Roberts CW, editors. Sex hormones and immunity to infection. Berlin: Springer; 2010. p. 123-46.

2. Muenchhoff M, Goulder PJ. Sex differences in pediatric infectious diseases. J Infect Dis. 2014;209(Suppl):S120-6.

3. Ghazeeri G, Abdullah L, Abbas O. Immunological differences in women compared with men: overview and contributing factors. Am J Reprod Immunol. 2011;66:163-9.

4. Garcia-Gomez E, Gonzalez-Pedrajo B, Camacho-Arroyo I. Role of sex steroid hormones in bacterial-host interactions. Biomed Res Int. 2013;2013:928290.

5. van Lunzen J, Altfeld M. Sex differences in infectious diseases-common but neglected. J Infect Dis. 2014;209(Suppl):S79-80.

6. Fish NF. The X-files in immunity: sex-based differences predispose immune responses. Nat Rev Immunol. 2008:8:734-7.

7. Klein SL, Jedlicka A, Pekosz A. The Xs and $Y$ of immune responses to viral vaccines. Lancet Infect Dis. 2010;10:338-49.

8. Pennell LM, Galligan CL, Fish EN. Sex affects immunity. J Autoimmun. 2012; 38:J282-91.

9. Camacho-Arroyo I, Hansberg-Pastor V, Vázquez-Martínez ER, Cerbón M. 3. 10--mechanism of progesterone action in the brain. In: Hormones, Brain and Behavior; 2017. p. 181-214

10. Sader MA, McGrath KC, Hill MD, Bradstock KF, Jimenez M, Handelsman DJ, et al. Androgen receptor gene expression in leucocytes is hormonally regulated: implications for gender differences in disease pathogenesis. Clin Endocrinol. 2005;62:56-63.

11. Angele MK, Schwacha MG, Ayala A, Chaudry IH. Effect of gender and sex hormones on immune responses following shock. Shock. 2000;14:81-90

12. Heldring N, Pike A, Andersson S, Matthews J, Cheng G, Hartman J, et al. Estrogen receptors: how do they signal and what are their targets. Physiol Rev. 2007:87:905-31.

13. Szekeres-Bartho J, Barakonyi A, Par G, Polgar B, Palkovics T, Szereday L. Progesterone as an immunomodulatory molecule. Int Immunopharmacol. 2001;:1:1037-48.

14. Robinson DP, Klein SL. Pregnancy and pregnancy-associated hormones alter immune responses and disease pathogenesis. Horm Behav. 2012;62:263-71. 
15. Kalkhoven E, Wissink S, van der Saag PT, van der Burg B. Negative interaction between the RelA(p65) subunit of NF-kappaB and the progesterone receptor. J Biol Chem. 1996;271:6217-24.

16. Hirano S, Furutama D, Hanafusa T. Physiologically high concentrations of 17beta-estradiol enhance NF-kappaB activity in human T cells. Am J Physiol Regul Integr Comp Physiol. 2007;292:R1465-71.

17. Trigunaite A, Dimo J, Jørgensen TN. Suppressive effects of androgens on the immune system. Cell Immunol. 2015;294:87-94.

18. Schröder J, Kahlke V, Staubach KH, Zabel P, Stüber F. Gender differences in human sepsis. Arch Surg. 1998;133:1200-5.

19. Grimaldi CM, Hill L, Xu X, Peeva E, Diamond B. Hormonal modulation of B cell development and repertoire selection. Mol Immunol. 2005;42:811-20.

20. Marriott I, Bost KL, Huet-Hudson YM. Sexual dimorphism in expression of receptors for bacterial lipopolysaccharides in murine macrophages: a possible mechanism for gender-based differences in endotoxic shock susceptibility. J Reprod Immunol. 2006;71:12-27.

21. Blackwell TS, Christman JW. Sepsis and cytokines: current status. Br J Anaesth. 1996;77:110-7.

22. Ackerman LS. Sex hormones and the genesis of autoimmunity. Arch Dermatol. 2006;142:371-6.

23. Aulock SV, Deininger S, Draing C, Gueinzius K, Dehus O, Hermann C. Gender difference in cytokine secretion on immune stimulation with LPS and LTA. J Interf Cytokine Res. 2006;26:887-92.

24. McClelland EE, Smith JM. Gender specific differences in the immune response to infection. Arch Immunol Ther Exp. 2011;59:203-13.

25. Giefing-Kroll C, Berger P, Lepperdinger G, Grubeck-Loebenstein B. How sex and age affect immune responses, susceptibility to infections, and response to vaccination. Aging Cell. 2015;14:309-21.

26. Giglio T, Imro MA, Filaci G, Scudeletti M, Puppo F, De Cecco L, et al. Immune cell circulating subsets are affected by gonadal function. Life Sci. 1994;54:1305-12.

27. Kumru S, Godekmerdan A, Yilmaz B. Immune effects of surgical menopause and estrogen replacement therapy in peri-menopausal women. J Reprod Immunol. 2004;63:31-8.

28. Marriott I, Huet-Hudson YM. Sexual dimorphism in innate immune responses to infectious organisms. Immunol Res. 2006;34:177-92.

29. Yasui T, Maegawa M, Tomita J, Miyatani Y, Yamada M, Uemura H, et al. Changes in serum cytokine concentrations during the menopausal transition. Maturitas. 2007;56:396-403.

30. Khan M. A plausible explanation for male dominance in typhoid ileal perforation. Clin Exp Gastroenterol. 2012;5:213-7.

31. Homma H, Hoy E, Xu DZ, Lu Q, Feinman R, Deitch EA. The female intestine is more resistant than the male intestine to gut injury and inflammation when subjected to conditions associated with shock states. Am J Physiol Gastrointest Liver Physiol. 2005;288:G466-72.

32. Kawasaki T, Suzuki T, Choudhry MA, Bland KI, Chaudry IH. Salutary effects of 17beta-estradiol on Peyer's patch T cell functions following traumahemorrhage. Cytokine. 2010;51:166-72.

33. Klein SL, Flanagan KL. Sex differences in immune responses. Nat Rev Immunol. 2016;16:626-38.

34. Faas M, Bouman A, Moesa $H$, Heineman MJ, de Leij L, Schuiling G. The immune response during the luteal phase of the ovarian cycle: a Th2-type response? Fertil Steril. 2000;74:1008-13.

35. Strauss JF. The synthesis and metabolism of steroid hormones. In: Yen, Jaffe's, editors. Reproductive Endocrinology. Philadelphia: Elsevier; 2014. p. 66-92.e3.

36. Scotland RS, Stables MJ, Madalli S, Watson P, Gilroy DW. Sex differences in resident immune cell phenotype underlie more efficient acute inflammatory responses in female mice. Blood. 2011;118:5918-27.

37. Strachan NJ, Watson RO, Novik V, Hofreuter D, Ogden ID, Galan JE. Sexual dimorphism in campylobacteriosis. Epidemiol Infect. 2008;136:1492-5.

38. Kaakoush NO, Castano-Rodriguez N, Mitchell HM, Man SM. Global epidemiology of campylobacter infection. Clin Microbiol Rev. 2015;28:687-720.

39. de Martel C, Parsonnet J. Helicobacter pylori infection and gender: a meta-analysis of population-based prevalence surveys. Dig Dis Sci. 2006; 51:2292-301.

40. Khatoon J, Rai RP, Prasad KN. Role of helicobacter pylori in gastric cancer: updates. World J Gastrointest Oncol. 2016:8:147-58

41. Campbell-Thompson M, Lauwers GY, Reyher KK, Cromwell J, Shiverick KT. 17Beta-estradiol modulates gastroduodenal preneoplastic alterations in rats exposed to the carcinogen $\mathrm{N}$-methyl-N'-nitro-nitrosoguanidine. Endocrinology. 1999;140:4886-94.
42. Ohtani M, Zhongming G, García A, Rogers AB, Muthupalani S, Taylor NS, et al. 17ß-estradiol suppresses helicobacter pylori-induced gastric pathology in male hypergastrinemic INS-GAS mice. Carcinogenesis. 2011;32:1244-50.

43. Messa C, Russo F, Pricci M, Di Leo A. Epidermal growth factor and 17betaestradiol effects on proliferation of a human gastric cancer cell line (AGS). Scand J Gastroenterol. 2000:35:753-8.

44. Martineti V, Picariello L, Tognarini I, Carbonell Sala S, Gozzini A, Azzari C, et al. ERbeta is a potent inhibitor of cell proliferation in the HCT8 human colon cancer cell line through regulation of cell cycle components. Endocr Relat Cancer. 2005;12:455-69.

45. Lu JY, Jin P, Gao W, Wang DZ, Sheng JQ. Estrogen enhances mismatch repair by induction of $\mathrm{MLH1}$ expression via estrogen receptor-beta. Oncotarget. 2017:8:38767-79.

46. Kable ME, Hansen LM, Styer CM, Deck SL, Rakhimova O, Shevtsova A, et al. Host determinants of expression of the helicobacter pylori BabA adhesin. Sci Rep. 2017;7:46499.

47. Potter VA, Aravinthan A. Identifying patients at risk of severe Clostridium difficile-associated disease. Br J Hosp Med. 2012;73:265-70.

48. Silva-Velazco J, Hull TL, Messick C, Church JM. Medical versus surgical patients with Clostridium difficile infection: is there any difference? Am Surg. 2016;82:1155-9.

49. Das R, Feuerstadt $P$, Brandt LJ. Glucocorticoids are associated with increased risk of short-term mortality in hospitalized patients with clostridium difficileassociated disease. Am J Gastroenterol. 2010;105:2040-9.

50. Liggins M, Ramirez N, Magnuson N, Abel-Santos E. Progesterone analogs influence germination of Clostridium sordellii and Clostridium difficile spores in vitro. J Bacteriol. 2011;193:2776-83.

51. Bancerz-Kisiel A, Szweda W. Yersiniosis--a zoonotic foodborne disease of relevance to public health. Ann Agric Env Med. 2015;22:397-402.

52. Rosner BM, Stark K, Werber D. Epidemiology of reported Yersinia enterocolitica infections in Germany, 2001-2008. BMC Public Health. 2010;10:337.

53. Rastawicki W, Jakubczak A. Serum immunoglobulin lgG subclass distribution of antibody responses to Yop proteins and lipopolysaccharide of Yersinia enterocolitica in patients with yersiniosis. Pol J Microbiol. 2007;56:233-8.

54. Aalberse RC, van der Gaag R, van Leeuwen J. Serologic aspects of lgG4 antibodies. I. Prolonged immunization results in an IgG4-restricted response. J Immunol. 1983:130:722-6.

55. Aalberse RC, Stapel SO, Schuurman J, Rispens T. Immunoglobulin G4: an odd antibody. Clin Exp Allergy. 2009:39:469-77.

56. Satoh M, Toma H, Kiyuna S, Shiroma Y, Kokaze A, Sato Y. Association of a sex-related difference of Strongyloides stercoralis-specific lgG4 antibody titer with the efficacy of treatment of strongyloidiasis. Am J Trop Med Hyg. 2004; 71:107-11.

57. Hlady WG, Klontz KC. The epidemiology of vibrio infections in Florida, 19811993. J Infect Dis. 1996;173:1176-83.

58. Chowdhury FR, Nur Z, Hassan N, von Seidlein L, Dunachie S. Pandemics, pathogenicity and changing molecular epidemiology of cholera in the era of global warming. Ann Clin Microbiol Antimicrob. 2017;16:10.

59. Eshima N, Tokumaru O, Hara S, Bacal K, Korematsu S, Karukaya S, et al. Agespecific sex-related differences in infections: a statistical analysis of national surveillance data in Japan. PLoS One. 2012;7:e42261.

60. Lee WC, Kwon YH. Comparative study on the epidemiological aspects of enterohemorrhagic Escherichia coli infections between Korea and Japan, 2006 to 2010. Korean J Intern Med. 2016:31:579-84.

61. Frank C, Werber D, Cramer JP, Askar M, Faber M, an der Heiden M, et al. Epidemic profile of Shiga-toxin-producing Escherichia coli 0104:H4 outbreak in Germany. N Engl J Med. 2011;365:1771-80.

62. Marshall JK, Thabane M, Garg AX, Clark WF, Salvadori M, Collins SM. Incidence and epidemiology of irritable bowel syndrome after a large waterborne outbreak of bacterial dysentery. Gastroenterology. 2006:131:445-50.

63. Schwille-Kiuntke J, Enck P, Zendler C, Krieg M, Polster AV, Klosterhalfen S, et al. Postinfectious irritable bowel syndrome: follow-up of a patient cohort of confirmed cases of bacterial infection with Salmonella or Campylobacter. Neurogastroenterol Motil. 2011;23:e479-88.

64. Bharadwaj S, Barber MD, Graff LA, Shen B. Symptomatology of irritable bowel syndrome and inflammatory bowel disease during the menstrual cycle. Gastroenterol Rep. 2015;3:185-93.

65. Zierau $\mathrm{O}$, Zenclussen $A C$, Jensen $F$. Role of female sex hormones, estradiol and progesterone, in mast cell behavior. Front Immunol. 2012;3:169. 
66. Gordon HS, Rosenthal GE. The relationship of gender and in-hospital death: increased risk of death in men. Med Care. 1999;37:318-24.

67. Falagas ME, Mourtzoukou EG, Vardakas KZ. Sex differences in the incidence and severity of respiratory tract infections. Respir Med. 2007;101:1845-63.

68. Assaggaf H, Felty Q. Gender, estrogen, and obliterative lesions in the lung. Int J Endocrinol. 2017;2017:1-13.

69. Sheikh SI, Hayes D, Kirkby SE, Tobias JD, Tumin D. Age-dependent gender disparities in post lung transplant survival among patients with idiopathic pulmonary fibrosis. Ann Thorac Surg. 2017;103:441-6.

70. Cohen S. Social status and susceptibility to respiratory infections. Ann N Y Acad Sci. 1999;896:246-53.

71. Haenle MM, Brockmann SO, Kron M, Bertling U, Mason RA, Steinbach G, et al. Overweight, physical activity, tobacco and alcohol consumption in a crosssectional random sample of German adults. BMC Public Health. 2006;6:233.

72. Kivihya-Ndugga LEA, van Cleeff MRA, Ng'ang'a LW, Meme H, Odhiambo JA, Klatser PR. Sex-specific performance of routine TB diagnostic tests. Int J Tuberc Lung Dis. 2005;9:294-300.

73. Gleeson M, Bishop N, Oliveira M, McCauley T, Tauler P. Sex differences in immune variables and respiratory infection incidence in an athletic population. Exerc Immunol Rev. 2011;17:122-35.

74. Chen Y, Dales R, Lin M. The epidemiology of chronic rhinosinusitis in Canadians. Laryngoscope. 2003;113:1199-205.

75. Gupta R, Helms PJ, Jolliffe IT, Douglas AS. Seasonal variation in sudden infant death syndrome and bronchiolitis--a common mechanism? Am J Respir Crit Care Med. 1996;154:431-5.

76. Abid S, Xie S, Bose M, Shaul PW, Terada LS, Brody SL, et al. 17ß-estradiol dysregulates innate immune responses to Pseudomonas aeruginosa respiratory infection and is modulated by estrogen receptor antagonism. Payne SM, editor Infect Immun 2017;85:e00422-e00417.

77. Cuzzocrea S, Santagati S, Sautebin L, Mazzon E, Calabrò G, Serraino I, et al. 17beta-estradiol antiinflammatory activity in carrageenan-induced pleurisy. Endocrinology. 2000;141:1455-63.

78. Ali AA, Diebel LN, Liberati DM. Estrogen modulation of pneumonia? An immunoglobulin A effect. J Trauma Acute Care Surg. 2012;72:908-15.

79. Gutiérrez F, Masiá M, Mirete C, Soldán B, Rodríguez JC, Padilla S, et al. The influence of age and gender on the population-based incidence of community-acquired pneumonia caused by different microbial pathogens. J Inf Secur. 2006;53:166-74.

80. Koh WP, Taylor MB, Hughes K, Chew SK, Fong CW, Phoon MC, et al. Seroprevalence of IgG antibodies against chlamydia pneumoniae in Chinese, Malays and Asian Indians in Singapore. Int J Epidemiol. 2002; 31:1001-7.

81. Kadioglu A, Cuppone AM, Trappetti C, List T, Spreafico A, Pozzi G, et al. Sexbased differences in susceptibility to respiratory and systemic pneumococcal disease in mice. J Infect Dis. 2011;204:1971-9.

82. Rivero-Calle I, Pardo-Seco J, Aldaz P, Vargas DA, Mascarós E, Redondo E, et al. Incidence and risk factor prevalence of community-acquired pneumonia in adults in primary care in Spain (NEUMO-ES-RISK project). BMC Infect Dis. 2016;16:645

83. Tamayo E, Montes M, Vicente D, Pérez-Trallero E. Streptococcus pyogenes pneumonia in adults: clinical presentation and molecular characterization of isolates 2006-2015. Chaussee MS, editor PLoS One. 2016;11:e0152640.

84. Simonetti AF, Garcia-Vidal C, Viasus D, Garcia-Somoza D, Dorca J, Gudiol F, et al. Declining mortality among hospitalized patients with communityacquired pneumonia. Clin Microbiol Infect. 2016;22:567.e1-7.

85. Backhaus E, Berg S, Andersson R, Ockborn G, Malmström P, Dahl M, et al. Epidemiology of invasive pneumococcal infections: manifestations, incidence and case fatality rate correlated to age, gender and risk factors. BMC Infect Dis. 2016;16:367.

86. Cukic $\mathrm{V}$, Hadzic A. The most common detected bacteria in sputum of patients with community acquired pneumonia (CAP) treated in hospital. Med Arch (Sarajevo, Bosnia Herzegovina). 2016;70:354-8.

87. Ishida T, Ito A, Washio Y, Yamazaki A, Noyama M, Tokioka F, et al. Risk factors for drug-resistant pathogens in immunocompetent patients with pneumonia: evaluation of PES pathogens. J Infect Chemother. 2017;23:23-8.

88. Prina E, Ranzani OT, Polverino E, Cillóniz C, Ferrer M, Fernandez L, et al. Risk factors associated with potentially antibiotic-resistant pathogens in community-acquired pneumonia. Ann Am Thorac Soc. 2015;12:153-60.

89. Cillóniz C, Gabarrús A, Ferrer M, Puig de la Bellacasa J, Rinaudo M, Mensa J, et al. Community-acquired pneumonia due to multidrug- and nonmultidrug-resistant Pseudomonas aeruginosa. Chest. 2016;150:415-25.
90. Lorente L, Jiménez A, Palmero S, Jiménez JJ, Iribarren JL, Santana M, et al. Comparison of clinical cure rates in adults with ventilator-associated pneumonia treated with intravenous ceftazidime administered by continuous or intermittent infusion: a retrospective, nonrandomized, openlabel, historical chart review. Clin Ther. 2007;29:2433-9.

91. Jaimes F, De La Rosa G, Gómez E, Múnera P, Ramírez J, Castrillón S. Incidence and risk factors for ventilator-associated pneumonia in a developing country: where is the difference? Respir Med. 2007;101:762-7.

92. Carcey J, Garcia P, Padilla O, Castro-Rodriguez JA. Increased prevalence of Mycoplasma pneumoniae serological positivity in Chilean young children. Allergol Immunopathol (Madr). 2016;44:467-71.

93. Nhamoyebonde S, Leslie A. Biological differences between the sexes and susceptibility to tuberculosis. J Infect Dis. 2014;209(Suppl):S100-6.

94. Narasimhan P, Wood J, Macintyre CR, Mathai D. Risk factors for tuberculosis. Pulm Med. 2013;2013:828939.

95. Jiménez-Corona M-E, García-García L, DeRiemer K, Ferreyra-Reyes L, Bobadilla-del-Valle M, Cano-Arellano B, et al. Gender differentials of pulmonary tuberculosis transmission and reactivation in an endemic area. Thorax. 2006;61:348-53.

96. Ephrem T, Mengiste B, Mesfin F, Godana W. Determinants of active pulmonary tuberculosis in Ambo Hospital, West Ethiopia. African J Prim Heal Care Fam Med. 2015;7 https://doi.org/10.4102/phcfm.v7i1.608.

97. Hong EP, Go MJ, Kim H-L, Park JW. Risk prediction of pulmonary tuberculosis using genetic and conventional risk factors in adult Korean population. Ahuja SK, editor PLoS One. 2017;12:e0174642.

98. Horton KC, MacPherson P, Houben RMGJ, White RG, Corbett EL. Sex differences in tuberculosis burden and notifications in low- and middleincome countries: a systematic review and meta-analysis. PLoS Med Public Libr Sci. 2016;13:e1002119.

99. Bhurayanontachai R, Maneenil K. Factors influencing development and mortality of acute respiratory failure in hospitalized patient with active pulmonary tuberculosis: a 10-year retrospective review. J Thorac Dis. 2016;8:1721-30.

100. Nnadi CD, Anderson LF, Armstrong LR, Stagg HR, Pedrazzoli D, Pratt R, et al. Mind the gap: TB trends in the USA and the UK, 2000-2011. Thorax. 2016; 71:356-63.

101. Khan AH, Israr M, Khan A, Aftab RA, Khan TM. Smoking on treatment outcomes among tuberculosis patients. Am J Med Sci. 2015;349:505-9.

102. Pimpin L, Drumright LN, Kruijshaar ME, Abubakar I, Rice B, Delpech V, et al. Tuberculosis and HIV co-infection in European Union and European Economic Area countries. Eur Respir J. 2011;38:1382-92.

103. Jeon CY, Murray MB. Diabetes mellitus increases the risk of active tuberculosis: a systematic review of 13 observational studies. Williams B, editor PLoS Med. 2008;5:e152.

104. Cabrera-Gaytán DA, Niebla-Fuentes MDR, Padilla-Velázquez R, Valle-Alvarado G, Arriaga-Nieto L, Rojas-Mendoza T, et al. Association of pulmonary tuberculosis and HIV in the Mexican Institute of Social Security, 2006-2014. Caylà JA, editor PLoS One. 2016;11:e0168559.

105. Rhodes SJ, Knight GM, Fielding K, Scriba TJ, Pathan AA, McShane H, et al. Individual-level factors associated with variation in mycobacterial-specific immune response: gender and previous BCG vaccination status. Tuberculosis. 2016;96:37-43.

106. Chavez K, Ravindran R, Dehnad A, Khan IH. Gender biased immunebiomarkers in active tuberculosis and correlation of their profiles to efficacy of therapy. Tuberculosis. 2016;99:17-24.

107. Brown J, Clark K, Smith C, Hopwood J, Lynard O, Toolan M, et al. Variation in C-reactive protein response according to host and mycobacterial characteristics in active tuberculosis. BMC Infect Dis. 2016;16:265.

108. Ramachandran G, Agibothu Kupparam HK, Vedhachalam C, Thiruvengadam K, Rajagandhi V, Dusthackeer A, et al. Factors influencing tuberculosis treatment outcome in adult patients treated with thrice-weekly regimens in India. Antimicrob Agents Chemother. 2017;61:e02464-16.

109. Neyrolles O, Quintana-Murci L. Sexual inequality in tuberculosis. PLoS Med. 2009;6:e1000199.

110. Stival A, Chiappini E, Montagnani C, Orlandini E, Buzzoni C, Galli L, et al. Sexual dimorphism in tuberculosis incidence: children cases compared to adult cases in Tuscany from 1997 to 2011. PLoS One. 2014;9:e105277.

111. Hamilton JB, Mestler GE. Mortality and survival: comparison of eunuchs with intact men and women in a mentally retarded population. J Gerontol. 1969; 24:395-411.

112. Svanberg L. Effects of estrogen deficiency in women castrated when young Acta Obstet Gynecol Scand Suppl. 1981;106:11-5. 
113. Dalgic N, Tekin D, Kayaalti Z, Cakir E, Soylemezoglu T, Sancar M. Relationship between toll-like receptor 8 gene polymorphisms and pediatric pulmonary tuberculosis. Dis Markers. 2011;31:33-8.

114. Bustamante J, Picard C, Boisson-Dupuis S, Abel L, Casanova J-L. Genetic lessons learned from X-linked Mendelian susceptibility to mycobacterial diseases. Ann N Y Acad Sci. 2011;1246:92-101.

115. Chan ED, Iseman MD. Slender, older women appear to be more susceptible to nontuberculous mycobacterial lung disease. Gend Med. 2010;7:5-18.

116. Danley J, Kwait R, Peterson DD, Sendecki J, Vaughn B, Nakisbendi K, et al. Normal estrogen, but low dehydroepiandrosterone levels, in women with pulmonary Mycobacterium avium complex. A preliminary study. Ann Am Thorac Soc. 2014;11:908-14.

117. Yamamoto Y, Saito H, Setogawa T, Tomioka H. Sex differences in host resistance to Mycobacterium marinum infection in mice. Infect Immun. 1991;59:4089-96.

118. Yamamoto Y, Tomioka H, Sato K, Saito H, Yamada Y, Setogawa T. Sex differences in the susceptibility of mice to infection induced by Mycobacterium intracellulare. Am Rev Respir Dis. 1990;142:430-3.

119. Tsuyuguchi K, Suzuki K, Matsumoto H, Tanaka E, Amitani R, Kuze F. Effect of oestrogen on Mycobacterium avium complex pulmonary infection in mice. Clin Exp Immunol. 2001;123:428-34.

120. Bini El, Mata Espinosa D, Marquina Castillo B, Barrios Payán J, Colucci D, Cruz $A F$, et al. The influence of sex steroid hormones in the immunopathology of experimental pulmonary tuberculosis. PLoS One. 2014;9:2-10.

121. Kleynhans L, Du Plessis N, Allie N, Jacobs M, Kidd M, van Helden PD, et al. The contraceptive depot medroxyprogesterone acetate impairs mycobacterial control and inhibits cytokine secretion in mice infected with Mycobacterium tuberculosis. Infect Immun. 2013;81:1234-44.

122. López-Olvera JR, Fernández-de-Mera IG, Serrano E, Vidal D, Vicente J, Fierro $Y$, et al. Sex-related differences in body condition and serum biochemical parameters in red deer (Cervus elaphus) naturally infected with Mycobacterium bovis. Vet J. 2013;198:702-6.

123. Tomlinson a J, Chambers M a, Wilson GJ, Mcdonald R a, Delahay RJ. Sex-related heterogeneity in the life-history correlates of mycobacterium bovis infection in european badgers (Meles meles). Transbound Emerg Dis. 2013;60:37-45.

124. Wilkinson D, Smith GC, Delahay RJ, Rogers LM, Cheeseman CL, Clifton-Hadley RS. The effects of bovine tuberculosis (Mycobacterium bovis) on mortality in a badger (Meles meles) population in England. J Zool. 2000;250:389-95.

125. Yancey AL, Watson HL, Cartner SC, Simecka JW. Gender is a major factor in determining the severity of mycoplasma respiratory disease in mice. Infect Immun. 2001;69:2865-71.

126. Wallis $L$, Robinson P. Soil as a source of Legionella pneumophila serogroup 1 (Lp1). Aust N Z J Public Health. 2005;29:518-20.

127. Declerck P, Behets J, van Hoef V, Ollevier F. Detection of Legionella spp. and some of their amoeba hosts in floating biofilms from anthropogenic and natural aquatic environments. Water Res. 2007;41:3159-67.

128. Joseph CA. Legionnaires' disease in Europe 2000-2002. Epidemiol Infect. 2004;132:417-24.

129. Benin AL, Benson RF, Besser RE. Trends in legionnaires disease, 19801998: declining mortality and new patterns of diagnosis. Clin Infect Dis. 2002:35:1039-46.

130. Quinn C, Demirjian A, Watkins LF, Tomczyk S, Lucas C, Brown E, et al. Legionnaires' disease outbreak at a long-term care facility caused by a cooling tower using an automated disinfection system--Ohio, 2013. J Environ Health. 2015;78:8-13.

131. Stypułkowska-Misiurewicz H, Czerwiński M. Legionellosis in Poland in 2012. Przegl Epidemiol. 2014;68(2):219-21.

132. Elverdal PL, Jørgensen CS, Krogfelt KA, Uldum SA. Two years' performance of an in-house ELISA for diagnosis of legionnaires' disease: detection of specific $\operatorname{lgM}$ and $\lg G$ antibodies against Legionella pneumophila serogroup 1, 3 and 6 in human serum. J Microbiol Methods. 2013;94:94-7.

133. Angrup A, Chaudhry R, Sharma S, Valavane A, Passi K, Padmaja K, et al. Application of real-time quantitative polymerase chain reaction assay to detect Legionella pneumophila in patients of community-acquired pneumonia in a tertiary care hospital. Indian J Med Microbiol. 2016;34:539.

134. Chidiac C, Che D, Pires-Cronenberger S, Jarraud S, Campèse C, Bissery A, et al. Factors associated with hospital mortality in community-acquired legionellosis in France. Eur Respir J. 2012;39:963-70.

135. Gómez J, Mòdol J, García-Núñez M, Baños V, Lorenzo M, Pedro-Botet ML, et al. Low mortality rate in an outbreak of Legionnaires' disease: correlation with the cytopathogenity study. Med Clin (Barc). 2009;133:325-9.
136. Ng V, Tang P, Jamieson F, Guyard C, Low DE, Fisman DN. Laboratory-based evaluation of legionellosis epidemiology in Ontario, Canada, 1978 to 2006. BMC Infect Dis. 2009;9:68.

137. Neil K, Berkelman R. Increasing incidence of legionellosis in the United States, 1990-2005: changing epidemiologic trends. Clin Infect Dis. 2008;47:591-9.

138. Matsumoto N, Sasaki T, Nakao H, Katoh T, Fukuda Y, Nakazato M, et al. An outbreak of Legionnaires' disease associated with a circulating bathwater system at a public bathhouse. II: radiological findings of pneumonia. J Infect Chemother. 2008;14:123-9.

139. den Boer JW, Friesema IHM, Hooi JD. Reported cases of Legionella pneumonia in the Netherlands, 1987-2000. Ned Tijdschr Geneeskd. 2002; 146:315-20.

140. Li JS, O'Brien ED, Guest C. A review of national legionellosis surveillance in Australia, 1991 to 2000. Commun Dis Intell Q Rep. 2002;26:461-8.

141. Han B-S, Lee M-J, Kwon Y-H, Lee W-C. A comparative study of the epidemiological aspects of Legionnaires' disease: outbreaks in Korea and Japan, 2010-2014. J Clin Med Res. 2017:9:67-70.

142. Rosenfeld M, Davis R, FitzSimmons S, Pepe M, Ramsey B. Gender gap in cystic fibrosis mortality. Am J Epidemiol. 1997;145:794-803.

143. Ramos KJ, Quon BS, Heltshe SL, Mayer-Hamblett N, Lease ED, Aitken ML, et al. Heterogeneity in survival in adult patients with cystic fibrosis with FEV 1 \&lt; 30\% of predicted in the United States. Chest. 2017;151:1320-8.

144. Magnet FS, Callegari J, Dieninghoff D, Spielmanns M, Storre JH, Schmoor C, et al. Impact of Pseudomonas aeruginosa infection on respiratory muscle function in adult cystic fibrosis patients. Respiration. 2017;93:42-50.

145. Johannesson M, Lúdvíksdóttir D, Janson C. Lung function changes in relation to menstrual cycle in females with cystic fibrosis. Respir Med. 2000; 94:1043-6.

146. Chotirmall SH, Smith SG, Gunaratnam C, Cosgrove S, Dimitrov BD, O'Neill SJ, et al. Effect of estrogen on pseudomonas mucoidy and exacerbations in cystic fibrosis. N Engl J Med. 2012;366:1978-86.

147. Chotirmall SH, Greene CM, Oglesby IK, Thomas W, O'Neill SJ, Harvey BJ, et al. 17Beta-estradiol inhibits IL-8 in cystic fibrosis by up-regulating secretory leucoprotease inhibitor. Am J Respir Crit Care Med. 2010;182:62-72.

148. Guilbault C, Stotland P, Lachance C, Tam M, Keller A, Thompson-Snipes L, et al. Influence of gender and interleukin-10 deficiency on the inflammatory response during lung infection with Pseudomonas aeruginosa in mice. Immunology. 2002:107:297-305.

149. Guilbault C, Martin P, Houle D, Boghdady M-L, Guiot M-C, Marion D, et al. Cystic fibrosis lung disease following infection with Pseudomonas aeruginosa in Cftr knockout mice using novel non-invasive direct pulmonary infection technique. Lab Anim. 2005;39:336-52.

150. Wang Y, Cela E, Gagnon S, Sweezey NB. Estrogen aggravates inflammation in Pseudomonas aeruginosa pneumonia in cystic fibrosis mice. Respir Res. 2010;11:166.

151. Wynne O, Horvat JC, Kim RY, Ong LK, Smith R, Hansbro PM, et al. Neonatal respiratory infection and adult re-infection: effect on glucocorticoid and mineralocorticoid receptors in the hippocampus in BALB/C mice. Brain Behav Immun. 2011;25:1214-22.

152. Kennedy SM, Chambers R, Du W, Dimich-Ward H. Environmental and occupational exposures: do they affect chronic obstructive pulmonary disease differently in women and men? Proc Am Thorac Soc. 2007;4:692-4.

153. Peters JM, Avol E, Gauderman WJ, Linn WS, Navidi W, London SJ, et al. A study of twelve Southern California communities with differing levels and types of air pollution. II. Effects on pulmonary function. Am J Respir Crit Care Med. 1999;159:768-75.

154. Medina-Ramón M, Schwartz J. Who is more vulnerable to die from ozone air pollution? Epidemiology. 2008;19:672-9.

155. Mikerov AN, Hu S, Durrani F, Gan X, Wang G, Umstead TM, et al. Impact of sex and ozone exposure on the course of pneumonia in wild type and SP-A (-/-) mice. Microb Pathog Elsevier Ltd. 2012;52:239-49.

156. Mikerov AN, Gan X, Umstead TM, Miller L, Chinchilli VM, Phelps DS, et al. Sex differences in the impact of ozone on survival and alveolar macrophage function of mice after Klebsiella pneumoniae infection. Respir Res. 2008:9:24.

157. Mikerov AN, Haque R, Gan X, Guo X, Phelps DS, Floros J. Ablation of SP-A has a negative impact on the susceptibility of mice to Klebsiella pneumoniae infection after ozone exposure: sex differences. Respir Res. 2008:9:77.

158. Cabello N, Mishra V, Sinha U, DiAngelo SL, Chroneos ZC, Ekpa NA, et al. Sex differences in the expression of lung inflammatory mediators in response to ozone. Am J Physiol Lung Cell Mol Physiol. 2015;309:L1150-63. 
159. Durrani F, Phelps DS, Weisz J, Silveyra P, Hu S, Mikerov AN, et al. Gonadal hormones and oxidative stress interaction differentially affects survival of male and female mice after lung Klebsiella pneumoniae infection. Exp Lung Res. 2012;38:165-72.

160. Remick DG. Pathophysiology of sepsis. Am J Pathol. 2007;170:1435-44.

161. Gannon CJ, Napolitano LM, Pasquale M, Tracy JK, McCarter RJ. A statewide population-based study of gender differences in trauma: validation of a prior single-institution study. J Am Coll Surg. 2002;195:11-8.

162. Choudhry MA, Bland Kl, Chaudry $\mathrm{H}$. Gender and susceptibility to sepsis following trauma. Endocr Metab Immune Disord Drug Targets. 2006;6:127-35.

163. Marini S, Morotti A, Lena UK, Goldstein JN, Greenberg SM, Rosand J, et al. Men experience higher risk of pneumonia and death after intracerebral hemorrhage. Neurocrit Care. 2018;28:77-82.

164. Humphreys H, Fitzpatick F, Harvey BJ. Gender differences in rates of carriage and bloodstream infection caused by methicillin-resistant Staphylococcus aureus: are they real, do they matter and why? Goldstein EJC, editor Clin Infect Dis. 2015;61:1708-1714.

165. Moore LJ, Moore FA, Jones SL, Xu J, Bass BL. Sepsis in general surgery: a deadly complication. Am J Surg. 2009;198:868-74.

166. Kisat M, Villegas CV, Onguti S, Zafar SN, Latif A, Efron DT, et al. Predictors of sepsis in moderately severely injured patients: an analysis of the National Trauma Data Bank. Surg Infect. 2013;14:62-8.

167. Lee C-C, Chu F-Y, Ko W-C, Chi C-H. Different clinical presentation of community-onset bacteremia among human immunodeficiency virusinfected and human immunodeficiency virus-uninfected adults in the ED. Am J Emerg Med. 2014;32:1241-7.

168. Jarrar D, Wang $P$, Cioffi WG, Bland $\mathrm{Kl}$, Chaudry $\mathrm{H}$. The female reproductive cycle is an important variable in the response to trauma-hemorrhage. Am J Physiol Heart Circ Physiol. 2000;279:H1015-21.

169. Mizushima $Y$, Wang $P$, Jarrar D, Cioffi WG, Bland Kl, Chaudry IH. Estradiol administration after trauma-hemorrhage improves cardiovascular and hepatocellular functions in male animals. Ann Surg. 2000;232:673-9.

170. Wichmann MW, Zellweger R, DeMaso CM, Ayala A, Chaudry IH. Mechanism of immunosuppression in males following trauma-hemorrhage: critical role of testosterone. Arch Surg. 1996;131:1186-91. discussion 1191-2

171. Knöferl MW, Jarrar D, Angele MK, Ayala A, Schwacha MG, Bland Kl, et al. 17 beta-estradiol normalizes immune responses in ovariectomized females after trauma-hemorrhage. Am J Physiol Cell Physiol. 2001;281:C1131-8.

172. Jarrar D, Wang P, Knöferl MW, Kuebler JF, Cioffi WG, Bland Kl, et al. Insight into the mechanism by which estradiol improves organ functions after trauma-hemorrhage. Surgery. 2000;128:246-52.

173. Mencacci A, Leli C, Cardaccia A, Meucci M, Moretti A, D'Alò F, et al. Procalcitonin predicts real-time PCR results in blood samples from patients with suspected sepsis. PLoS One. 2012;7:e53279.

174. Oberholzer A, Keel M, Zellweger R, Steckholzer U, Trentz O, Ertel W. Incidence of septic complications and multiple organ failure in severely injured patients is sex specific. J Trauma. 2000;48:932-7.

175. Frink M, Pape H-C, van Griensven M, Krettek C, Chaudry IH, Hildebrand F. Influence of sex and age on mods and cytokines after multiple injuries. Shock. 2007;27:151-6.

176. Wang HE, Shapiro NI, Griffin R, Safford MM, Judd S, Howard G. Inflammatory and endothelial activation biomarkers and risk of sepsis: a nested casecontrol study. J Crit Care. 2013;28:549-55.

177. Adrie C, Azoulay E, Francais A, Clec'h C, Darques L, Schwebel C, et al. Influence of gender on the outcome of severe sepsis: a reappraisal. Chest. 2007;132:1786-93.

178. Bindl L, Buderus S, Dahlem P, Demirakca S, Goldner M, Huth R, et al. Gender-based differences in children with sepsis and ARDS: the ESPNIC ARDS database group. Intensive Care Med. 2003;29:1770-3.

179. Casimir GJ, Heldenbergh F, Hanssens L, Mulier S, Heinrichs C, Lefevre N, et al. Gender differences and inflammation: an in vitro model of blood cells stimulation in prepubescent children. J Inflamm (Lond). 2010;7:28.

180. Zellweger R, Wichmann MW, Ayala A, Stein S, DeMaso CM, Chaudry $\mathbb{H}_{\text {. }}$ Females in proestrus state maintain splenic immune functions and tolerate sepsis better than males. Crit Care Med. 1997;25:106-10.

181. Newsome CT, Flores E, Ayala A, Gregory S, Reichner JS. Improved antimicrobial host defense in mice following poly-(1,6)- $\beta$-D-glucopyranosyl$(1,3)-\beta$-D-glucopyranose glucan treatment by a gender-dependent immune mechanism. Clin Vaccine Immunol. 2011;18:2043-9.

182. Angele MK, Catania RA, Ayala A, Cioffi WG, Bland Kl, Chaudry IH. Dehydroepiandrosterone: an inexpensive steroid hormone that decreases the mortality due to sepsis following trauma-induced hemorrhage. Arch Surg. 1998;133:1281-8.

183. Catania RA, Angele MK, Ayala A, Cioffi WG, Bland Kl, Chaudry $\Perp H$. Dehydroepiandrosterone restores immune function following traumahaemorrhage by a direct effect on T lymphocytes. Cytokine. 1999;11:443-50.

184. Wichmann MW, Müller C, Meyer G, Adam M, Angele MK, Eisenmenger SJ, et al. Different immune responses to abdominal surgery in men and women. Langenbecks Arch Surg. 2003;387:397-401.

185. Rettew JA, Huet-Hudson YM, Marriott I. Testosterone reduces macrophage expression in the mouse of toll-like receptor 4 , a trigger for inflammation and innate immunity. Biol Reprod. 2008;78:432-7.

186. Diodato MD, Knöferl MW, Schwacha MG, Bland Kl, Chaudry $\Vdash H$. Gender differences in the inflammatory response and survival following haemorrhage and subsequent sepsis. Cytokine. 2001;14:162-9.

187. Drechsler S, Weixelbaumer K, Raeven P, Jafarmadar M, Khadem A, van Griensven $M$, et al. Relationship between age/gender-induced survival changes and the magnitude of inflammatory activation and organ dysfunction in post-traumatic sepsis. PLoS One. 2012;7:e51457.

188. Caruso JM, Xu DZ, Lu Q, Dayal SD, Deitch EA. The female gender protects against pulmonary injury after trauma hemorrhagic shock. Surg Infect. 2001;2:231-40.

189. Hsieh Y-C, Frink M, Hsieh C-H, Choudhry MA, Schwacha MG, Bland Kl, et al. Downregulation of migration inhibitory factor is critical for estrogenmediated attenuation of lung tissue damage following trauma-hemorrhage. Am J Physiol Lung Cell Mol Physiol. 2007;292:L1227-32.

190. Hsieh Y-C, Frink M, Kawasaki T, Thobe BM, Choudhry MA, Schwacha MG, et al. Downregulation of TLR4-dependent ATP production is critical for estrogen-mediated immunoprotection in Kupffer cells following traumahemorrhage. J Cell Physiol. 2007;211:364-70.

191. Hsieh Y-C, Frink M, Thobe BM, Hsu J-T, Choudhry MA, Schwacha MG, et al 17Beta-estradiol downregulates Kupffer cell TLR4-dependent p38 MAPK pathway and normalizes inflammatory cytokine production following trauma-hemorrhage. Mol Immunol. 2007:44:2165-72.

192. Angele MK, Knöferl MW, Ayala A, Bland Kl, Chaudry IH. Testosterone and estrogen differently effect Th1 and Th2 cytokine release following traumahaemorrhage. Cytokine. 2001;16:22-30.

193. Angele MK, Ayala A, Cioffi WG, Bland Kl, Chaudry IH. Testosterone: the culprit for producing splenocyte immune depression after trauma hemorrhage. Am J Phys. 1998;274:C1530-6.

194. Mayr S, Walz CR, Angele P, Hernandez-Richter T, Chaudry IH, Loehe F, et al. Castration prevents suppression of MHC class II (la) expression on macrophages after trauma-hemorrhage. J Appl Physiol. 2006;101:448-53.

195. Angele MK, Wichmann MW, Ayala A, Cioffi WG, Chaudry IH. Testosterone receptor blockade after hemorrhage in males. Restoration of the depressed immune functions and improved survival following subsequent sepsis. Arch Surg. 1997;132:1207-14

196. Hildebrand F, Thobe BM, Hubbard WJ, Choudhry MA, Pape H-C, Chaudry $\mathbb{H}$. Effects of 17beta-estradiol and flutamide on splenic macrophages and splenocytes after trauma-hemorrhage. Cytokine. 2006;36:107-14.

197. Moxley G, Stern AG, Carlson P, Estrada E, Han J, Benson LL. Premenopausal sexual dimorphism in lipopolysaccharide-stimulated production and secretion of tumor necrosis factor. J Rheumatol. 2004;31:686-94.

198. Asai K, Hiki N, Mimura Y, Ogawa T, Unou K, Kaminishi M. Gender differences in cytokine secretion by human peripheral blood mononuclear cells: role of estrogen in modulating LPS-induced cytokine secretion in an ex vivo septic model. Shock. 2001;16:340-3.

199. Coyle SM, Calvano SE, Lowry SF. Gender influences in vivo human responses to endotoxin. Shock. 2006;26:538-43.

200. Merkel SM, Alexander S, Zufall E, Oliver JD, Huet-Hudson YM. Essential role for estrogen in protection against Vibrio vulnificus-induced endotoxic shock. Infect Immun. 2001;69:6119-22

201. Iwasa T, Matsuzaki T, Kinouchi R, Gereltsetseg G, Murakami M, Munkhzaya M, et al. Changes in central and peripheral inflammatory responses to lipopolysaccharide in ovariectomized female rats. Cytokine. 2014;65:65-73.

202. Iwasa T, Matsuzaki T, Matsui S, Tungalagsuvd A, Munkhzaya M, Takiguchi E, et al. The sensitivity of adipose tissue visfatin mRNA expression to lipopolysaccharide-induced endotoxemia is increased by ovariectomy in female rats. Int Immunopharmacol. 2016;35:243-7.

203. Shen $H-H$, Huang S-Y, Cheng P-Y, Chu Y-J, Chen S-Y, Lam K-K, et al. Involvement of HSP70 and $\mathrm{HO}-1$ in the protective effects of raloxifene on multiple organ dysfunction syndrome by endotoxemia in ovariectomized rats. Menopause. 2017;24:959-69. 
204. Ongaro L, Castrogiovanni D, Giovambattista A, Gaillard RC, Spinedi E. Enhanced proinflammatory cytokine response to bacterial lipopolysaccharide in the adult male rat after either neonatal or prepubertal ablation of biological testosterone activity. Neuroimmunomodulation. 2011; 18:254-60.

205. Carroll JA, Burdick Sanchez NC, Hulbert LE, Ballou MA, Dailey JW, Caldwell $L C$, et al. Sexually dimorphic innate immunological responses of prepubertal Brahman cattle following an intravenous lipopolysaccharide challenge. Vet Immunol Immunopathol. 2015;166:108-15.

206. van Eijk LT, Dorresteijn MJ, Smits P, van der Hoeven JG, Netea MG, Pickkers $P$. Gender differences in the innate immune response and vascular reactivity following the administration of endotoxin to human volunteers. Crit Care Med. 2007;35:1464-9.

207. Hajjeh RA, Reingold A, Weil A, Shutt K, Schuchat A, Perkins BA. Toxic shock syndrome in the United States: surveillance update, 1979, 1996. Emerg Infect Dis. 1999:5:807-10.

208. Proft T, Fraser JD. Bacterial superantigens. Clin Exp Immunol. 2003;133: 299-306.

209. Faulkner L, Cooper A, Fantino C, Altmann DM, Sriskandan S. The mechanism of superantigen-mediated toxic shock: not a simple Th1 cytokine storm. J Immunol. 2005;175:6870-7

210. Arad G, Levy R, Kaempfer R. Superantigen concomitantly induces Th1 cytokine genes and the ability to shut off their expression on re-exposure to superantigen. Immunol Lett. 2002;82:75-8.

211. Faulkner L, Altmann DM, Ellmerich S, Huhtaniemi I, Stamp G, Sriskandan S. Sexual dimorphism in superantigen shock involves elevated TNFalpha and TNF-alpha induced hepatic apoptosis. Am J Respir Crit Care Med. 2007;176:473-82.

212. Saia RS, Garcia FM, Cárnio EC. Estradiol protects female rats against sepsis induced by Enterococcus faecalis improving leukocyte bactericidal activity. Steroids. 2015;102:17-26.

213. Yeretssian G, Doiron K, Shao W, Leavitt BR, Hayden MR, Nicholson DW, et al. Gender differences in expression of the human caspase-12 long variant determines susceptibility to Listeria monocytogenes infection. Proc Nat Acad Sci U S A. 2009;106:9016-20.

214. Chandra R, Federici S, Németh ZH, Horváth B, Pacher P, Haskó G, et al. Female X-chromosome mosaicism for NOX2 deficiency presents unique inflammatory phenotype and improves outcome in polymicrobial sepsis. J Immunol. 2011;186:6465-73.

215. Spolarics Z. The $X$-files of inflammation: cellular mosaicism of $X$-linked polymorphic genes and the female advantage in the host response to injury and infection. Shock. 2007;27:597-604.

216. Chandra R, Federici S, Németh ZH, Csóka B, Thomas JA, Donnelly R, et al. Cellular mosaicism for X-linked polymorphisms and IRAK1 expression presents a distinct phenotype and improves survival following sepsis. J Leukoc Biol. 2014;95:497-507.

217. Manukyan MC, Weil BR, Wang Y, Abarbanell AM, Herrmann JL, Poynter JA, et al. Female stem cells are superior to males in preserving myocardial function following endotoxemia. Am J Physiol Regul Integr Comp Physiol. 2011;300:R1506-14.

218. Chamekh M, Deny M, Romano M, Lefèvre N, Corazza F, Duchateau J, et al. Differential susceptibility to infectious respiratory diseases between males and females linked to sex-specific innate immune inflammatory response. Front Immunol. 2017:8:1806.

219. Eisenmenger SJ, Wichmann MW, Angele P, Faist E, Hatz R, Chaudry $\mathbb{H}_{\text {, et al. }}$ Differences in the expression of LPS-receptors are not responsible for the sex-specific immune response after trauma and hemorrhagic shock. Cell Immunol. 2004;230:17-22.

220. Shimizu T, Yu H-P, Hsieh Y-C, Choudhry MA, Suzuki T, Bland Kl, et al. Flutamide attenuates pro-inflammatory cytokine production and hepatic injury following trauma-hemorrhage via estrogen receptor-related pathway. Ann Surg. 2007;245:297-304.

221. Sharawy N, Ribback S, Al-Banna N, Lehmann C, Kern H, Wendt M, et al. Estradiol receptors agonists induced effects in rat intestinal microcirculation during sepsis. Microvasc Res. 2013;85:118-27.

222. Suzuki T, Shimizu T, Yu H-P, Hsieh Y-C, Choudhry MA, Schwacha MG, et al. Tissue compartment-specific role of estrogen receptor subtypes in immune cell cytokine production following trauma-hemorrhage. J Appl Physiol. 2007; 102:163-8.

223. Suzuki T, Shimizu T, Yu HP, Hsieh YC, Choudhry MA, Bland KICl. Estrogen receptor-alpha predominantly mediates the salutary effects of 17 beta- estradiol on splenic macrophages following trauma-hemorrhage. Am J Physiol Cell Physiol. 2007;293:C978-84.

224. Yu H-P, Hsieh Y-C, Suzuki T, Shimizu T, Choudhry MA, Schwacha MG, et al. Salutary effects of estrogen receptor-beta agonist on lung injury after trauma-hemorrhage. Am J Physiol Lung Cell Mol Physiol. 2006;290:L1004-9.

225. Suzuki T, Shimizu T, Yu H-P, Hsieh Y-C, Choudhry MA, Chaudry $\Vdash H$. Salutary effects of 17beta-estradiol on T-cell signaling and cytokine production after trauma-hemorrhage are mediated primarily via estrogen receptor-alpha. Am J Physiol Cell Physiol. 2007;292:C2103-11.

226. Shimizu T, Yu H-P, Suzuki T, Szalay L, Hsieh Y-C, Choudhry MA, et al. The role of estrogen receptor subtypes in ameliorating hepatic injury following trauma-hemorrhage. J Hepatol. 2007:46:1047-54.

227. Cristofaro PA, Opal SM, Palardy JE, Parejo NA, Jhung J, Keith JC, et al. WAY202196, a selective estrogen receptor-beta agonist, protects against death in experimental septic shock. Crit Care Med. 2006;34:2188-93.

228. Angele MK, Pratschke S, Hubbard WJ, Chaudry IH. Gender differences in sepsis: cardiovascular and immunological aspects. Virulence. 2014;5:12-9.

229. Fabbian F, De Giorgi A, Lopez-Soto PJ, Pala M, Tiseo R, Cultrera R, et al. Is female gender as harmful as bacteria? Analysis of hospital admissions for urinary tract infections in elderly patients. J Womens Heal. 2015;24:587-92.

230. Harper M, Fowlis G. 3. Management of urinary tract infections in men. Trends Urol Gynaecol Sex Heal Wiley-Blackwell. 2007;12:30-5.

231. Sonnex C. Influence of ovarian hormones on urogenital infection. Sex Transm Infect. 1998;74:11-9.

232. Jarefors S, Bennet L, You E, Forsberg P, Ekerfelt C, Berglund J, et al. Lyme borreliosis reinfection: might it be explained by a gender difference in immune response? Immunology. 2006;118:224-32.

233. Tveitnes D, Oymar K. Gender differences in childhood Lyme neuroborreliosis. Behav Neurol. 2015;2015:790762.

234. Morrison CS, Bright P, Wong EL, Kwok C, Yacobson I, Gaydos CA, et al. Hormonal contraceptive use, cervical ectopy, and the acquisition of cervical infections. Sex Transm Dis. 2004;31:561-7.

235. Hafner LM, Cunningham K, Beagley KW. Ovarian steroid hormones: effects on immune responses and Chlamydia trachomatis infections of the female genital tract. Mucosal Immunol. 2013;6:859-75.

236. Bose SK, Goswami PC. Enhancement of adherence and growth of Chlamydia trachomatis by estrogen treatment of HeLa cells. Infect Immun. 1986;53:646-50.

237. Agrawal T, Vats V, Wallace PK, Salhan S, Mittal A. Cervical cytokine responses in women with primary or recurrent chlamydial infection. J Interf Cytokine Res. 2007;27:221-6.

238. Kita E, Takahashi S, Yasui K, Kashiba S. Effect of estrogen (17 beta-estradiol) on the susceptibility of mice to disseminated gonococcal infection. Infect Immun. 1985;49:238-43.

239. Edwards JL. Neisseria gonorrhoeae survival during primary human cervical epithelial cell infection requires nitric oxide and is augmented by progesterone. Infect Immun. 2010;78:1202-13.

240. Cossart P, Lebreton A. A trip in the "new microbiology" with the bacterial pathogen Listeria monocytogenes. FEBS Lett. 2014;588: 2437-45.

241. Pasche B, Kalaydjiev S, Franz TJ, Kremmer E, Gailus-Durner V, Fuchs H, et al. Sex-dependent susceptibility to Listeria monocytogenes infection is mediated by differential interleukin-10 production. Infect Immun. 2005;73: 5952-60.

242. Salem ML, Matsuzaki G, Madkour GA, Nomoto K. Beta-estradiol-induced decrease in IL-12 and TNF-alpha expression suppresses macrophage functions in the course of Listeria monocytogenes infection in mice. Int J Immunopharmacol. 1999;21:481-97.

243. Leone M, Honstettre A, Lepidi H, Capo C, Bayard F, Raoult D, et al. Effect of sex on Coxiella burnetii infection: protective role of 17beta-estradiol. J Infect Dis. 2004;189:339-45.

244. Textoris J, Ban LH, Capo C, Raoult D, Leone M, Mege JL. Sex-related differences in gene expression following Coxiella burnetii infection in mice: potential role of circadian rhythm. PLoS One. 2010;5:e12190.

245. Oliver JD. Wound infections caused by Vibrio vulnificus and other marine bacteria. Epidemiol Infect. 2005;133:383-91.

246. Horseman MA, Surani S. A comprehensive review of Vibrio vulnificus: an important cause of severe sepsis and skin and soft-tissue infection. Int J Infect Dis. 2011;15:e157-66.

247. Shiau HJ, Reynolds MA. Sex differences in destructive periodontal disease: exploring the biologic basis. J Periodontol. 2010;81:1505-17. 
248. Cotti E, Zedda A, Deidda M, Piras A, Flore G, Ideo F, et al. Endodontic infection and endothelial dysfunction are associated with different mechanisms in men and women. J Endod. 2015;41:594-600.

249. Gomes MS, Blattner TC, Sant'Ana Filho M, Grecca FS, Hugo FN, Fouad AF, et al. Can apical periodontitis modify systemic levels of inflammatory markers? A systematic review and meta-analysis. J Endod. 2013;39:1205-17.

250. Mansur N, Hazzan R, Paul M, Bishara J, Leibovici L. Does sex affect 30-day mortality in Staphylococcus aureus bacteremia? Gend Med. 2012;9:463-70

251. Uslan DZ, Crane SJ, Steckelberg JM, Cockerill FR, St Sauver JL, Wilson WR, et al. Age- and sex-associated trends in bloodstream infection: a populationbased study in Olmsted County, Minnesota. Arch Intern Med. 2007;167:8349.

252. Vidal PM, Trindade PA, Garcia TO, Pacheco RL, Costa SF, Reinert C, et al. Differences between "classical" risk factors for infections caused by methicillin-resistant Staphylococcus aureus (MRSA) and risk factors for nosocomial bloodstream infections caused by multiple clones of the staphylococcal cassette chromosome mec type IV MRSA strain. Infect Control Hosp Epidemiol. 2009;30:139-45.

253. Carnicer-Pont D, Bailey KA, Mason BW, Walker AM, Evans MR, Salmon RL. Risk factors for hospital-acquired methicillin-resistant Staphylococcus aureus bacteraemia: a case-control study. Epidemiol Infect. 2006;134:1167-73.

254. Maclayton DO, Suda KJ, Coval KA, York CB, Garey KW. Case-control study of the relationship between MRSA bacteremia with a vancomycin MIC of 2 microg/mL and risk factors, costs, and outcomes in inpatients undergoing hemodialysis. Clin Ther. 2006;28:1208-16.

255. Suryati BA, Watson M. Staphylococcus aureus bacteraemia in children: a 5 year retrospective review. J Paediatr Child Health. 2002;38:290-4.

256. Laupland KB, Lyytikäinen O, Søgaard M, Kennedy K, Knudsen JD, Ostergaard C, et al. The changing epidemiology of Staphylococcus aureus bloodstream infection: a multinational population-based surveillance study. Clin Microbiol Infect. 2013;19:465-71.

257. Kaasch AJ, Barlow G, Edgeworth JD, Fowler VG, Hellmich M, Hopkins S, et al. Staphylococcus aureus bloodstream infection: a pooled analysis of five prospective, observational studies. J Infect. 2014;68:242-51.

258. Lessa FC, Mu Y, Davies J, Murray M, Lillie M, Pearson A, et al. Comparison of incidence of bloodstream infection with methicillin-resistant Staphylococcus aureus between England and United States, 2006-2007. Clin Infect Dis. 2010;51:925-8.

259. Laupland KB, Schønheyder HC, Kennedy KJ, Lyytikäinen O, Valiquette L, Galbraith J, et al. Salmonella enterica bacteraemia: a multi-nationa population-based cohort study. BMC Infect Dis. 2010;10:95.

260. Gudiol C, Calatayud L, Garcia-Vidal C, Lora-Tamayo J, Cisnal M, Duarte R, et al. Bacteraemia due to extended-spectrum beta-lactamase-producing Escherichia coli (ESBL-EC) in cancer patients: clinical features, risk factors, molecular epidemiology and outcome. J Antimicrob Chemother 2010;65:333-41.

261. Olesen B, Kolmos HJ, Orskov F, Orskov I, Gottschau A. Bacteraemia due to Escherichia coli in a Danish university hospital, 1986-1990. Scand J Infect Dis. 1995;27:253-7.

262. Hansen DS, Gottschau A, Kolmos HJ. Epidemiology of Klebsiella bacteraemia: a case control study using Escherichia coli bacteraemia as control. J Hosp Infect. 1998;38:119-32.

263. Laupland KB, Ross T, Church DL, Gregson DB. Population-based surveillance of invasive pyogenic streptococcal infection in a large Canadian region. Clin Microbiol Infect. 2006;12:224-30.

264. Llopis F, Grau I, Tubau F, Cisnal M, Pallares R. Epidemiological and clinical characteristics of bacteraemia caused by Aeromonas spp. as compared with Escherichia coli and Pseudomonas aeruginosa. Scand J Infect Dis. 2004;36:335-41.

\section{Ready to submit your research? Choose BMC and benefit from:}

- fast, convenient online submission

- thorough peer review by experienced researchers in your field

- rapid publication on acceptance

- support for research data, including large and complex data types

- gold Open Access which fosters wider collaboration and increased citations

- maximum visibility for your research: over $100 \mathrm{M}$ website views per year

At BMC, research is always in progress.

Learn more biomedcentral.com/submissions 